Article

\title{
Nonparametric Approach to Evaluation of Economic and Social Development in the EU28 Member States by DEA Efficiency
}

\author{
Lukáš Melecký $^{1} \mathbb{D}$, Michaela Staníčková ${ }^{1, * \mathbb{D}}$ and Jana Hančlová ${ }^{2}$ \\ 1 Department of European Integration, Faculty of Economics, VŠB-Technical University of Ostrava, \\ Sokolská třída 33, 70200 Ostrava 1, Czech Republic; lukas.melecky@vsb.cz \\ 2 Department of System Engeneering, Faculty of Economics, VŠB-Technical University of Ostrava, \\ Sokolská třída 33, 70200 Ostrava 1, Czech Republic; jana.hanclova@vsb.cz \\ * Correspondence: michaela.stanickova@vsb.cz; Tel.: +420-597-322-237
}

Received: 27 March 2019; Accepted: 22 April 2019; Published: 24 April 2019

\begin{abstract}
Data envelopment analysis (DEA) methodology is used in this study for a comparison of the dynamic efficiency of European countries over the last decade. Moreover, efficiency analysis is used to determine where resources are distributed efficiently and/or were used efficiently/inefficiently under factors of competitiveness extracted from factor analysis. DEA measures numerical grades of the efficiency of economic processes within evaluated countries and, therefore, it becomes a suitable tool for setting an efficient/inefficient position of each country. Most importantly, the DEA technique is applied to all (28) European Union (EU) countries to evaluate their technical and technological efficiency within the selected factors of competitiveness based on country competitiveness index in the 2000-2017 reference period. The main aim of the paper is to measure efficiency changes over the reference period and to analyze the level of productivity in individual countries based on the Malmquist productivity index (MPI). Empirical results confirm significant disparities among European countries and selected periods 2000-2007, 2008-2011, and 2012-2017. Finally, the study offers a comprehensive comparison and discussion of results obtained by MPI that indicate the EU countries in which policy-making authorities should aim to stimulate national development and provide more quality of life to the EU citizens.
\end{abstract}

Keywords: competitiveness; country competitiveness index; DEA; efficiency; European Union; factors; indicators; Malmquist productivity index

\section{Introduction}

It is generally accepted that the level of economic development is not uniform across territories. On the contrary, it substantially differs. This plays an essential role in many research studies that sought to assign an appropriate evaluation of economic and social development in the European area (e.g., Balcerowicz et al. 2013; Easterly and Levine 2012; Watt and Botsch 2010; Ghosh et al. 2009). As human activities are related to economic development and affected by territorial development, the way of measurement of the conditions of national development is essential in the determination of a country's socio-economic policies (Halkos and Tzeremes 2005). The issue of socio-economic advancement, as well as disparities of territories, is closely linked to the setting and evaluation of competitiveness (Gardiner et al. 2004; Lukovics 2009; Ocubo 2012).

The pursuit and the promotion of competitiveness increasingly shape the dynamics of economic, social, political, and cultural change in the contemporary world. The economy's entry into the globalization phase radically altered the nature of competition. Numerous new actors from every market in the world are simultaneously in competition on every market. This new competition 
accentuated the interdependence of the different levels of globalization. Globalization obliged all countries to raise their standards of economic efficiency, resulting in a growing interest in and concern about competitiveness; nations, regions, and cities have no option but to strive to be competitive in order to survive in the new global marketplace and the "new competition" being forged by the further information or knowledge-driven economy (Gardiner et al. 2004).

Policy-makers at all levels are being swept up in this competitiveness fever. This growing interest may perhaps be partly attributable to their awareness of the fact that all countries have to contend with raised standards of economic efficiency as a result of the globalization of goods and factor markets. The economy may be competitive, but if the society and the environment suffer too much, the country will face significant difficulties and vice versa. Therefore, governments, in the long run, cannot focus alone on the economic competitiveness of their country; instead, they need an integrated approach to govern the country. The complexity of competitiveness, decomposed by Esser et al. (1995), in the view of efficiency analysis is used in this paper-every country has standard features which affect and drive the competitiveness of all the entities located there, even if the variability of competitiveness level of the entities within the country may be very high.

In the European Union (EU), the process of achieving an increasing trend and a higher level of competitiveness is significantly complicated by the heterogeneity of countries and regions in many areas. Although the EU is one of the most developed parts of the world with high living standards, there exist significant and substantial economic, social, and territorial disparities influencing a level of worldwide production and efficiency; so far, the EU competitiveness stands as a global player in the world economy. Considering the increasing importance of economic growth in the society and competitive world, evaluation of territorial performance is remarkably considered, and various measures are brought up as criteria in the assessment of territorial performance. The EU competitiveness depends on a multiplicity of actions that can optimize the potentials within its countries. All EU member states possess development opportunities; however, enough use of these options will increase the competitiveness of the EU countries and, thus, they must be efficient enough.

From this point of view, the purpose of the paper is to achieve a more detailed productivity analysis and assessment of EU28 countries based on the concept of country competitiveness index (Annoni and Kozovska 2010; Annoni and Dijkstra 2013; Annoni et al. 2017) using a multivariate method of factor analysis (FA), identifying the main factors of socioeconomic development determining the competitiveness level of European countries. These factors of competitiveness are used for further productivity score evaluation performed using an advanced data envelopment analysis (DEA) approach-Malmquist productivity index (MPI) (Färe et al. 1994a, 1994b) in the reference period 2000-2017. The application of MPI allows providing an efficiency analysis of EU member states in three selected periods, 2000-2007 (pre-crisis period), 2008-2011 (crisis period), and 2012-2017 (post-crisis period), concerning the internal and external assumption for their economic growth and competitive position.

\section{Theoretical Background}

At a time when the EU member states have to deal with increased pressure on public balances, stemming from demographic trends and globalization, the improvement of the efficiency and effectiveness of public spending features high on the political agenda. The current economic situation determined by persisting effects of the crisis is causing the governments of countries worldwide to streamline their processes in terms of collecting revenue from the state budget and then redistributing it on the principle of performance and economic efficiency. Therefore, this resulted in the fact that markets provided by developed countries will be more critical for developing countries and their trade practices, as well as commercial practices of national or/and private companies (MacGregor Pelikánová 2017). Comparative analysis of efficiency in the public sector is, thus, a starting point for studying the role of efficiency, effectiveness, and total performance regarding economic governance of resource utilization by general management for achieving medium/long-term objectives of economic recovery and sustainable development of national economies (Mihaiu et al. 2010). 
The analysis of efficiency and effectiveness is about the relationships between inputs (entries), outputs (results), and outcomes (effects). Farrell (1957) already investigated the question of how to measure efficiency and highlighted its relevance for economic policy-makers. Since that time, techniques to measure efficiency improved, and investigations of efficiency are more frequent. Nevertheless, the measurement of efficiency and effectiveness of countries remains a conceptual challenge. Problems arise because public spending has multiple objectives and because public sector outputs are often not sold on the market, which implies that price data are not available and that the output cannot be quantified (Mandl et al. 2008). Efficiency is, thus, a central issue in analyses of economic growth, the effects of fiscal policies, the pricing of capital assets, the level of investments, the technology changes and production technology, and other economic topics and indicators. Efficiency can be achieved under the conditions of maximizing the results of action about the resources used, and it is calculated by comparing the effects obtained by their efforts. In a competitive economy, therefore, the issue of efficiency, particularly dynamic efficiency, can be resolved by comparing these economic issues.

The ratio of inputs to outputs gives the efficiency, but there is a difference between the technical efficiency and the allocative efficiency. The technical efficiency implies a relationship between inputs and outputs on the frontier production curve; however, not any form of technical efficiency makes sense in economic terms, and this efficiency is captured through the allocative efficiency that requires a cost/benefit ratio. The effectiveness, in terms of this meaning, implies a relationship between outputs and outcomes. In this sense, the distinction between the output and the outcome must be made. The outcome is often linked to welfare or growth objectives and, therefore, may be influenced by multiple factors (including outputs, as well as exogenous "environment" factors). The effectiveness is, thus, more challenging to assess than efficiency, since the outcome is influenced by political choice. There are thus three key topics for the article concept: competitiveness-productivity-stage of development, and their interdependence is as follows, resp. for the logical interconnection of theoretical and empirical part see Figure 1.

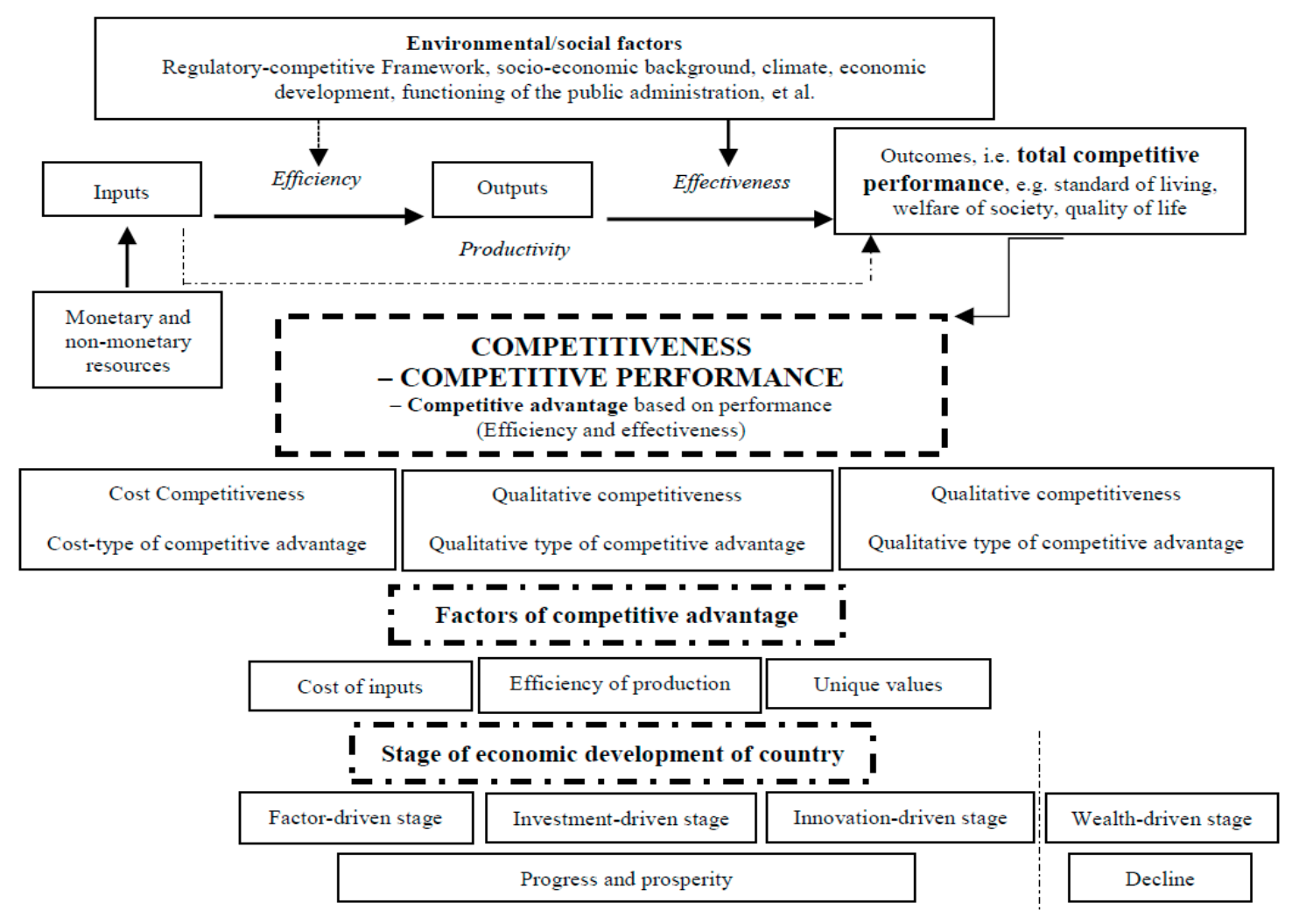

Figure 1. The relationship between the efficiency and the effectiveness impacting competitiveness (source: Mandl et al. 2008; own extension and elaboration). 
Drucker (2001) believes that there is no efficiency without effectiveness because it is more important to do well what you proposed (the effectiveness) than do well something else that was not necessarily concerned. The relationship between efficiency and effectiveness is that of a part to the whole; the effectiveness is a necessary condition for achieving efficiency. This implies that efficiency and effectiveness are not always easy to isolate.

\section{Materials and Methods}

The most common quantitative methods convenient for a high number of multivariate measured variables can be identified as multivariate statistical methods. Multivariate analysis is an ever-expanding set of techniques for data analysis, encompassing a wide range of possible research situations (Hair et al. 2009). Between collections of multivariate statistical methods, we can include, e.g., principal component analysis, factor analysis, cluster analysis, or data envelopment analysis.

\subsection{Factor Analysis}

Many scientific studies feature the fact that "numerous variables are used to characterize objects". Because of these big numbers of variables that are in play, the study can become rather complicated. Moreover, it could well be that some of the variables measure different aspects of the same underlying variable. For situations such as these, factor analysis (FA) was invented. FA is the statistical approach that can be used to analyze interrelationships among a large number of variables and to explain these variables in terms of their standard underlying dimensions, i.e., factors. The main applications of FA techniques are, thus, to reduce the number of variables and to detect structure in the relationships among variables, so as to classify variables. The objective of FA is to reduce the number of variables by grouping them into a smaller set of factors; for this purpose, FA is applied in the paper.

FA is a collection of methods for investigating whether some variables of interest $\left(Y_{1}, Y_{2}, \ldots, Y_{n}\right)$ are linearly related to a smaller number of unobservable factors $\left(F_{1}, F_{2}, \ldots, F_{k}\right)$. If we suggest that one measured variable, $Y_{1}$, is a function of two underlying factors, $F_{1}$ and $F_{2}$, then it is assumed that $Y$ variable is linearly related to the two factors $F$, as follows (Hair et al. 2009):

$$
Y_{1}=\beta_{10}+\beta_{11} F_{1}+\beta_{12} F_{2}+e_{1}
$$

The error terms $e_{1}$ serves to indicate that the hypothesized relationships are not exact. In the specialized vocabulary of FA, the parameters $\beta_{i, j}$ are referred to as loadings, e.g., $\beta_{12}$ is called the loading of variable $Y_{1}$ on factor $F_{2}$.

Why carry out factor analyses? If we can summarize a multitude of measurements with a smaller number of factors without losing too much information, we achieve some economy of description, which is one of the goals of scientific investigation. It is also possible that FA will allow us to test theories involving variables, which are hard to measure directly. Finally, at a more prosaic level, FA can help us establish that sets of questionnaire items (observed variables) are in fact all measuring the same underlying factor (perhaps with varying reliability) and, hence, can be combined to form a more reliable measure of that factor. There are some different varieties of FA (Stevens 1986).

For an elaboration of FA, the software IBM SPSS Statistics 25 is used in the paper.

\subsection{DEA-Based Malmquist Productivity Index}

Charnes et al. (1978) first proposed data envelopment analysis (DEA). Since DEA was first introduced, researchers in some fields quickly recognized that it is an excellent and easily used methodology for modeling operational processes for efficiency evaluations, accompanied by other developments. There are several researchers which also employed the DEA method in the context of studies about a country's macroeconomy and Knowledge-based economies (KBE) (see Appendix A); Melecký (2018) and Staníčková (2017) also consider DEA as a convenient tool for measuring efficiency as a mirror of national and regional competitiveness. Several studies using the DEA approach also focused 
its attention on efficiency analysis in the context of EU member states in research and development (Conte et al. 2009).

DEA is based on the simple Farrell model (Farrell 1957) for measuring the efficiency of decision-making units (DMUs) with one input and one output. This method was initially expanded in 1978 by Charnes, Cooper, and Rhodes (CCR model) assuming constant returns to scale (CRS), and it was later modified in 1984 by Banker, Charnes, and Cooper (BCC model) assuming variable returns to scale (VRS). DEA methods also include advanced additive models, such as the slack-based model (SBM) performed by Tone in 2002 or free disposal hull (FDH) and free replicability hull (FRH) models that were firstly formulated in 1984 by Deprins, Simar, and Tulkens. In recent years, research efforts focused on the investigation of the causes of productivity change and its decomposition. Malmquist productivity index (MPI) became the standard approach in productivity measurement over time within nonparametric research. MPI was introduced firstly by Caves et al. (1982). Färe et al. (1994a, 1994b) defined and applied an input-oriented productivity index as the geometric mean of the two MPIs developed by Caves et al. Although it was developed in a consumer context, MPI recently enjoyed widespread use in a production context. MPI can be used to construct indexes of input, output, or productivity, as ratios of input or output distance functions. There are various methods for measuring distance functions, and the most famous one is the linear programming method. MPI allows measuring of total productivity using distance-function calculation, which can be estimated from a solution of mathematical programming problems of the DEA kind.

With respect to the nonparametric approach, it is worth mentioning differences between parametric and nonparametric methods in statistics, especially concerning the fact that we use several descriptive statistics in the paper. Methods are classified by what we know about the population we are studying. Parametric methods are typically the first methods studied in an introductory statistics course. The basic idea is that there is a set of fixed parameters that determine a probability model. Parametric methods are often those for which we know that the population is approximately normal, or we can approximate using a normal distribution after we invoke the central limit theorem. There are two parameters for a normal distribution: mean and standard deviation. To contrast with parametric methods, we define nonparametric methods. These are statistical techniques for which we do not have to make any assumption of parameters for the population we are studying. Indeed, the methods do not have any dependence on the population of interest. The set of parameters is no longer fixed, and neither is the distribution that we use. It is for this reason that nonparametric methods are also referred to as distribution-free methods. Nonparametric methods are growing in popularity and influence for some reasons. The main reason is that we are not constrained as much as when we use a parametric approach. We do not need to make as many assumptions about the population that we are working with as what we have to make with a parametric approach. Many of these nonparametric methods are easy to apply and to understand. It is safe to say that most people who use statistics are more familiar with parametric analyses than nonparametric analyses. What is the comparison of both methods? There are multiple ways to use statistics to find a confidence interval about a mean. The parametric method would involve the calculation of a margin of error with a formula, and the estimation of the population mean with a sample mean. The nonparametric method to calculate confidence mean would involve the use of bootstrapping. Why do we need both parametric and nonparametric methods for this type of problem? Many times, parametric methods are more efficient than the corresponding nonparametric methods. Although this difference in efficiency is typically not that much of an issue, there are instances where we do need to consider which method is more efficient. Concerning statistical error, the difference lies in the fact that nonparametric methods (data envelopment analysis, DEA) use optimization to solve statistical errors, and parametric methods (stochastic frontier analysis, SFA) use econometrics to resolve statistical errors.

As mentioned above, empirical analysis is based on a frontier nonparametric approach and aims to study productivity growth and efficiency. This part of the analysis is based on MPI for measuring the change of technical efficiency and the movement of the frontier in terms of individual DMUs 
(Färe et al. 1994a, 1994b). Suppose we have a production function in period $t$ as well as period $t+1$. MPI calculation requires two single-period and two mixed-period measures. The two single-period measures can be obtained using the CCR CRS model. For simplicity of MPI calculation, it is presented as a basic DEA model based on the assumption of single input/output. With regard to the selected type of DEA model and its assumptions, it is still appropriate to mention here the general way of model selection. The classic input-oriented DEA model can be specified under the condition that the production function has constant returns to scale (CRS). If the production function has variable returns to scale (VRS), there may be returns to scale (RTS) described as increasing (IRTS) or decreasing (DRTS). The selection of the DEA model based on RTS can be assessed according to three methods, as specified Seiford and Zhu (1999), i.e., CCR RTS method, BCC RTS method, and scale efficiency index method. For evaluation of territorial efficiency, DEA in the form of the CRS model is often used, e.g., Lacko and Hajduová (2018), Makridou et al. (2014), Otsuka (2014), or Malhotra and Malhotra (2006).

Suppose each $D M U_{j}(j=1,2, \ldots n)$ produces a vector of output $y_{j}^{t}=\left(y_{1 j}^{t}, \ldots, y_{s j}^{t}\right)$ by using a vector of inputs $x_{j}^{t}=\left(x_{1 j^{\prime}}^{t}, \ldots, x_{m j}^{t}\right)$ at each period $t, t=1, \ldots, T$. From time $t$ to time $t+1, D M U_{0^{\prime}} \mathrm{s}$ efficiency may change and/or the frontier may shift. MPI is calculated via Equation (2) comparing $x_{0}^{t}$ to the frontier at time $t$, i.e., calculating $\theta_{0}^{t}\left(x_{0}^{t}, y_{0}^{t}\right)$ in the following input-oriented IO CCR CRS envelopment model (Zhu 2011):

$$
\theta_{0}^{t}\left(x_{0}^{t}, y_{0}^{t}\right)=\min \theta_{0}
$$

subject to

$$
\begin{gathered}
\sum_{j=1}^{n} \lambda_{j} x_{j}^{t} \leq \theta_{0} x_{0}^{t}, \\
\sum_{j=1}^{n} \lambda_{j} y_{j}^{t} \geq y_{0}^{t}, \\
\lambda_{j} \geq 0, j=1, \ldots, n,
\end{gathered}
$$

where $\theta_{0}$ indicates the efficiency score of observed $D M U_{0}$, and $x_{0}^{t}=\left(x_{10}^{t}, \ldots, x_{m 0}^{t}\right)$ and $y_{0}^{t}=\left(y_{10}^{t}, \ldots, y_{s 0}^{t}\right)$ are the input and the output vectors of $D M U_{0}$ among others.

MPI is further calculated via Equation (3) comparing $x_{0}^{t+1}$ to the frontier at time $t+1$, i.e., calculating $\theta_{0}^{t+1}\left(x_{0}^{t+1}, y_{0}^{t+1}\right)$ in the following input-oriented CCR CRS envelopment model (Zhu 2011):

$$
\theta_{0}^{t+1}\left(x_{0}^{t+1}, y_{0}^{t+1}\right)=\min \theta_{0}
$$

subject to

$$
\begin{gathered}
\sum_{j=1}^{n} \lambda_{j} x_{j}^{t+1} \leq \theta_{0} x_{0}^{t+1}, \\
\sum_{j=1}^{n} \lambda_{j} y_{j}^{t+1} \geq y_{0}^{t+1}, \\
\lambda_{j} \geq 0, j=1, \ldots, n .
\end{gathered}
$$

MPI is further calculated via Equation (4) comparing $x_{0}^{t}$ to the frontier at time $t+1$, i.e., calculating $\theta_{0}^{t+1}\left(x_{0}^{t}, y_{0}^{t}\right)$ via the following linear program (Zhu 2011):

$$
\theta_{0}^{t+1}\left(x_{0}^{t}, y_{0}^{t}\right)=\min \theta_{0}
$$

subject to

$$
\begin{gathered}
\sum_{j=1}^{n} \lambda_{j} x_{j}^{t+1} \leq \theta_{0} x_{0}^{t} \\
\sum_{j=1}^{n} \lambda_{j} x_{j}^{t+1} \geq y_{0}^{t} \\
\lambda_{j} \geq 0, j=1, \ldots, n .
\end{gathered}
$$


MPI is further calculated via Equation (5) comparing $x_{0}^{t+1}$ to the frontier at time $t$, i.e., calculating $\theta_{0}^{t}\left(x_{0}^{t+1}, y_{0}^{t+1}\right)$ via the following linear program (Zhu 2011):

$$
\theta_{0}^{t}\left(x_{0}^{t+1}, y_{0}^{t+1}\right)=\min \theta_{0}
$$

subject to

$$
\begin{gathered}
\sum_{j=1}^{n} \lambda_{j} x_{j}^{t} \leq \theta_{0} x_{0}^{t+1}, \\
\sum_{j=1}^{n} \lambda_{j} y_{j}^{t} \geq y_{0}^{t+1}, \\
\lambda_{j} \geq 0, j=1, \ldots, n .
\end{gathered}
$$

MPI measuring the efficiency change of production units between successive periods $t$ and $t+1$, is formulated via Equation (6).

$$
M_{0}\left(x^{t+1}, y^{t+1}, x^{t}, y^{t}\right)=E C H_{0} \cdot F S_{0}
$$

where $E C H_{0}$ is the change in the relative efficiency of $D M U_{0}$ about other units (i.e., due to the production possibility frontier) between periods $t$ and $t+1$. $F S_{0}$ describes the change in the production possibility frontier as a result of the technology development between periods $t$ and $t+1$. The formulation of MPI in Equation (7) makes it possible to measure the change of technical efficiency and the movement of the frontier in terms of a specific $D M U_{0}$ (Zhu 2011).

$$
M_{0}=\frac{\theta_{0}^{t}}{\theta_{0}^{t+1}\left(x_{0}^{t+1}, y_{0}^{t+1}\right)}\left[\frac{\theta_{0}^{t+1}\left(x_{0}^{t+1}, y_{0}^{t+1}\right)}{\theta_{0}^{t}\left(x_{0}^{t+1}, y_{0}^{t+1}\right)} \cdot \frac{\theta_{0}^{t+1}\left(x_{0}^{t}, y_{0}^{t}\right)}{\theta_{0}^{t}\left(x_{0}^{t}, y_{0}^{t}\right)}\right]^{\frac{1}{2}} .
$$

\begin{tabular}{|c|c|c|c|}
\hline MPI & Productivity & ECH & FS \\
\hline MPI > 1 & Improving & Change $>1$, improving & Change $>1$, improving \\
\hline $\mathrm{MPI}=1$ & Unchanging & Change $=1$, unchanging & Change $=1$, unchanging \\
\hline $\mathrm{MPI}<1$ & Declining & Change $<1$, declining & Change $<1$, declining \\
\hline
\end{tabular}

The first component on the right-hand side measures the magnitude of technical efficiency change between periods $t$ and $t+1$, indicating that technical efficiency improves, remains, or declines. The second term measures the shift in the possibility frontier, i.e., technology frontier shift, between periods $t$ and $t+1$. Trends in MPI, ECH, and FS are illustrated in Table 1.

Table 1. Trends in Malmquist productivity index (MPI) and its components (source: Zhu 2011).

DEA is a popular method for general business management because it has a number of advantages: (1) it can evaluate a DMU's performance with multiple inputs and multiple outputs (fulfilling the criteria of our dataset, i.e., many input and output factors based on the number of numerous initial indicators); (2) it allows the units of input and output variables to be different (again, this criterion meets the paper outline, where the dataset represents various aspects of competitiveness on both side of input and output indicators); and (3) it is not necessary to know the type of production function in advance. However, DEA also has several limitations: (1) the DMUs must be homogeneous (in our case, the criterion of homogeneity represent 28 countries of the EU); (2) to obtain the best results, the number of DMUs must be at least twice the total number of input and output variables (this condition is fulfilled as the following paragraph and equations explain); and (3) isotonicity must exist, that is, the output must not decrease while the input increases (this condition is met as confirmed in the following paragraph). 
If a performance measure (input/output) is added or deleted from consideration, it will influence the relative efficiencies. Empirically, when the number of performance measures is high in comparison with the number of DMUs, then most of the DMUs are evaluated efficiently. Hence, the obtained results are not reliable. There is a rule of thumb proposed by Cooper et al. (2007) which expresses the relationship between the number of DMUs and the number of performance measures. Toloo et al. (2015) checked more than 40 papers that contain practical applications and, statistically, they found out that, in nearly all of the cases, the number of inputs and outputs did not exceed six. Suppose there are $n$ DMUs which consume $m$ inputs to produce $s$ outputs. A simple calculation shows that when $m \leq 6$ and $s \leq 6$, then $3(m+s) \geq m \times s$. As a result, in this paper, the following formula is applied:

$$
n \geq 3(m+s)
$$

In the article, this rule is met, i.e., the number of DMUs is three times higher than the sum of inputs and outputs, i.e., $28 \geq 3(6+3)$.

In this section, we check the validity of the model in terms of the model specification and the existence of potential outliers in the sample. Firstly, we introduce the isotonicity test for checking the validity of the model specification. Specifically, we checked whether an increase in input indicators brought growth in outputs rather than a decrease in outputs (see Avkiran 2006; Adusei 2016; Hwang et al. 2018; Jiang and He 2018). Input data for the DEA model must meet the isotonicity criteria, i.e., the level of outputs is at least the same, and does not fall when inputs increase. More specifically, the requirement is that the relationship between inputs and outputs is not erratic. Increasing the value of any input while keeping other factors constant should not decrease any output but should instead lead to an increase in the value of at least one output. By calculating the correlations between the input and output variables, we found that, if the pairwise correlation is statistically significant at $5 \%$ level of significance, the correlation moves in the range from 0.49 to 0.69 with one exception. Only in the case of input factor 2 (level of infrastructure) and output factor 3 (labor market) was there a correlation $(-0.13)$. These results of the isotonicity test justify the selection of variables.

Secondly, we conducted outlier detection with the idea of a scatter matrix, especially using boxplots and the number of extreme outliers. Based on the assumptions for principal component analysis (PCA), we use standardized variables for the extraction of rotated factors using SPSS Statistics, which recommends determining extreme outliers as component scores with values out of interval (quartile $1-3 \times$ IQR; quartile $3+3 \times$ IQR). According to Chandola et al. (2009) or Jiang and $\mathrm{He}$ (2018), this methodology is simple and widely used. We performed the procedure and calculated the accumulated times that the data of a country are considered to be an outlier with the value of component scores out of interval (quartile $1-1.5 \times \mathrm{IQR}$; quartile $3+1.5 \times \mathrm{IQR}$ ). The results show that there are outliers, but they are more or less exceptions. In the case of input factors, we found that Germany and the United Kingdom in factor 2 (infrastructure), Malta in factor 5 (participation in education), and Bulgaria in factor 6 (expenditure on education and civilization diseases) outperformed the other countries during some but not all years of the reference period 2000-2017. In the case of output factors, we found that only Spain in factor 2 (knowledge-based economy) outperformed the other countries during some but not all years of the reference period 2000-2017. In the case of outliers, the DEA method might be inconsistent. Because these countries were outliers and not extreme outliers, present only in some input or output factors and not in all years of the reference period, they were left within the framework of the evaluation.

For the solution of the DEA method, a software tool based on solving linear programming problems is used in the paper-Solver in MS Excel 2016, similar to DEA Frontier.

\section{Results}

The empirical analysis starts by building a database of indicators that are part of the country competitiveness index (CCI) approach created by Annoni and Kozovska (2010) in 2010, and then 
updated by Annoni and Dijkstra (2013) and Annoni et al. (2017). CCI also has its dimension in the regional competitiveness index (RCI). The roots of $\mathrm{CCI} / \mathrm{RCI}$ lay in the most known competitiveness indicator, the global competitiveness index reported by the World Economic Forum. Pillars of $\mathrm{CCI} / \mathrm{RCI}$ are grouped according to the different dimensions (input versus output aspects) of national competitiveness they describe. The terms "inputs" and "outputs" are meant to classify pillars into those which describe driving forces of competitiveness, in terms of long-term potentiality, and those which are direct or indirect outcomes of a competitive society and economy Annoni and Kozovska (2010).

The CCI/RCI data file consisted of 66 indicators in 2010, 73 indicators in 2013, and 74 indicators in 2016; however, not all indicators are used in the paper because of a lack of data for every country within EU28-15 countries are classified as old EU member states (origin countries from 1957 and countries joining the European community in 1973, 1981, 1986, and 1995), and 13 countries belong to the group of new EU member states (joining the EU in 2004, 2007, and 2013). Some indicators are excluded from analysis because of a lack of data for many of countries and periods; from this point of view, only 61 indicators are used in the paper-37 represent inputs, and 24 represent outputs (see Table 2). Related to the issue of the nature of the dataset and individual indicators, the used database includes quantitative (numerical) indicators with the exact measured values, and not qualitative (categorical) indicators. The data source for downloading these indicators was the European Statistical Office (Eurostat).

Table 2. Country competitiveness index (CCI) indicators in input and output dimensions * (source: own elaboration).

\begin{tabular}{|c|c|c|}
\hline Dimension & Pillar & Indicator of Input \\
\hline \multirow{6}{*}{ Input } & Institution & $\begin{array}{l}\text { Political stability (PS), voice and accountability (VA), } \\
\text { government effectiveness (GE), regulatory quality (RQ), rule of } \\
\text { law (RL), control of corruption (CC) }\end{array}$ \\
\hline & Macroeconomic stability & $\begin{array}{l}\text { Harmonized index of consumer prices (HICP), gross fixed } \\
\text { capital formation (GFCF), income, saving, and net lending/net } \\
\text { borrowing (ISLB), total intramural research and development } \\
\text { expenditure (GERD), labor productivity per person employed } \\
\text { (LPPE) }\end{array}$ \\
\hline & Infrastructure & $\begin{array}{l}\text { Railway transport-length of tracks (RTLT), air transport of } \\
\text { passengers (ATP), volume of passenger transport (VPT), } \\
\text { volume of freight transport (VFT), motorway } \\
\text { transport-length of motorways (MTLM), air transport of } \\
\text { freight (ATF) }\end{array}$ \\
\hline & Health & $\begin{array}{l}\text { Healthy life expectancy (HLE), infant mortality rate (IMR), } \\
\text { cancer disease death rate (CDDR), heart disease death rate } \\
\text { (HDDR), suicide death rate (SDR), hospital beds (HB), road } \\
\text { fatalities (RF) }\end{array}$ \\
\hline & $\begin{array}{l}\text { Primary, secondary and } \\
\text { tertiary education; training } \\
\text { and lifelong learning }\end{array}$ & $\begin{array}{l}\text { Mathematics, science, and technology enrolments and } \\
\text { graduates (MSTEG), pupils to teachers ratio (PTR), financial } \\
\text { aid to students (FAS), total public expenditure at primary level } \\
\text { of education (TPEPLE), total public expenditure at secondary } \\
\text { level of education (TPESLE), total public expenditure at } \\
\text { tertiary level of education (TPETLE), participants in early } \\
\text { education (PEE), participation in higher education (PHE), } \\
\text { early leavers from education and training (ELET), accessibility } \\
\text { to universities (AU), lifelong learning-participation in } \\
\text { education and training (LLPET) }\end{array}$ \\
\hline & $\begin{array}{l}\text { Indicators for technological } \\
\text { readiness }\end{array}$ & Level of internet access (LIA), E-government availability (EA) \\
\hline
\end{tabular}


Table 2. Cont.

\begin{tabular}{|c|c|c|}
\hline Dimension & Pillar & The Indicator of Output * \\
\hline \multirow{4}{*}{ Output } & Labor market efficiency & $\begin{array}{l}\text { Labor productivity (LP), male employment (ME), female } \\
\text { employment (FE), male unemployment (MU), female } \\
\text { unemployment (FU), Public expenditure on labor market } \\
\text { policies (PEoLMP), employment rate (15 to } 64 \text { years) } \\
\text { (ER15to64), long-term unemployment (LtUR), unemployment } \\
\text { rate (UR) }\end{array}$ \\
\hline & Market size & $\begin{array}{l}\text { Gross domestic product (GDP), compensation of employees } \\
\text { (CoE), disposable income (DI) }\end{array}$ \\
\hline & Business sophistication & $\begin{array}{l}\text { Gross value added in sophisticated sectors (GVA), } \\
\text { employment in sophisticated sectors (EiSS) }\end{array}$ \\
\hline & Innovation & $\begin{array}{l}\text { Human resources in science and technology (HRST), total } \\
\text { patent applications (TPAp), employment in technology and } \\
\text { knowledge-intensive sectors by education (ETKIedu), } \\
\text { employment in technology and knowledge-intensive sectors } \\
\text { by gender (ETKIgen), employment in technology and } \\
\text { knowledge-intensive sectors by type of occupation (ETKIocc), } \\
\text { human resources in science and technology-core (HRSTcore), } \\
\text { patent applications to the European Patent Office (EPO), } \\
\text { high-tech patent applications to the EPO (HTI), Information } \\
\text { and Communication Technologies (ICT) patent applications to } \\
\text { EPO (ICT), biotechnology patent applications to the } \\
\text { EPO (BioT) }\end{array}$ \\
\hline
\end{tabular}

${ }^{*}$ Due to the extent of the dataset, the authors applied restrictions on data availability.

The reference period consists of years 2000, 2007, 2008, 2011, 2012, and 2017, whereas years are divided into three groups according to the different period of economic cycles they describe. The period of years 2000 to 2007 characterizes a growth period in all evaluated countries and the pre-crisis period; years 2008 to 2011 are part of the period which represents crisis; and years 2012 to 2017 constitute the post-crisis period.

\section{Key Factors of Competitiveness at the EU National Level}

What is the background of national competitiveness? What are the key factors having an impact on competitive advantages and disadvantages of nations? What are the crucial factors behind competitive differences and gaps among countries? These are the kinds of questions that motivate the empirical study of aspects of EU member state competitiveness. Especially currently, when governments of countries deal with the impact of the crisis, the policy-makers need a clear sense of its current competitive position, its functioning, and latent factors of competitiveness: the new starting point. By understanding both its position and factors of competitiveness, the policy-makers could better understand the potential development options and also limitations for countries to know which activities are necessary to boost and which ones to limit, followed by plotting a development trajectory toward the desired end state, as mentioned by Martin (2003).

In the following analysis, the key factors of competitiveness for the EU28 member states are described. The first part of FA is devoted to input factors of competitiveness; it means driven forces of competitiveness. Driven forces of competitiveness are divided into factors that are crucial for EU economies. In this paper, six dominating factors for inputs explained $68.098 \%$ of the total variability in the reference period (see Table 3), which can be considered as a satisfactory result. For calculation of input factors by FA, principal component analysis was used as the extraction method, and varimax with Kaiser normalization was used as the rotation method. 
Table 3. Input factors- total variance explained (source: own calculation and elaboration).

\begin{tabular}{ccccccc}
\hline \multirow{2}{*}{ Component } & \multicolumn{3}{c}{ Initial Eigenvalues } & \multicolumn{2}{c}{ Rotation Sums of Squared Loadings } \\
\cline { 2 - 6 } & Total & \% of Variance & Cumulative $\%$ & Total & \% of Variance & Cumulative \% \\
\hline 1 & 10.540 & 30.115 & 30.115 & 9.112 & 26.033 & 26.033 \\
2 & 5.223 & 14.923 & 45.038 & 5.604 & 16.011 & 42.044 \\
3 & 2.523 & 7.209 & 52.247 & 2.505 & 7.158 & 49.203 \\
4 & 2.163 & 6.180 & 58.428 & 2.436 & 6.960 & 56.162 \\
5 & 1.880 & 5.372 & 63.799 & 2.177 & 6.220 & 62.382 \\
6 & 1.504 & 4.298 & 68.098 & 2.001 & 5.716 & 68.098 \\
\hline 7 & 1.362 & 3.892 & 71.990 & & & \\
8 & 1.233 & 3.523 & 75.513 & & & \\
9 & 1.061 & 3.031 & 78.544 & & & \\
\hline
\end{tabular}

Table 4 shows 37 indicators (initial FA) and their relevant input factors of competitiveness. Input factors of competitiveness for the EU member states are divided into several areas of the national economy, which are currently key and necessary for an economy based on knowledge and innovation.

Table 4. Input factors-rotated component matrix (source: own calculation and elaboration).

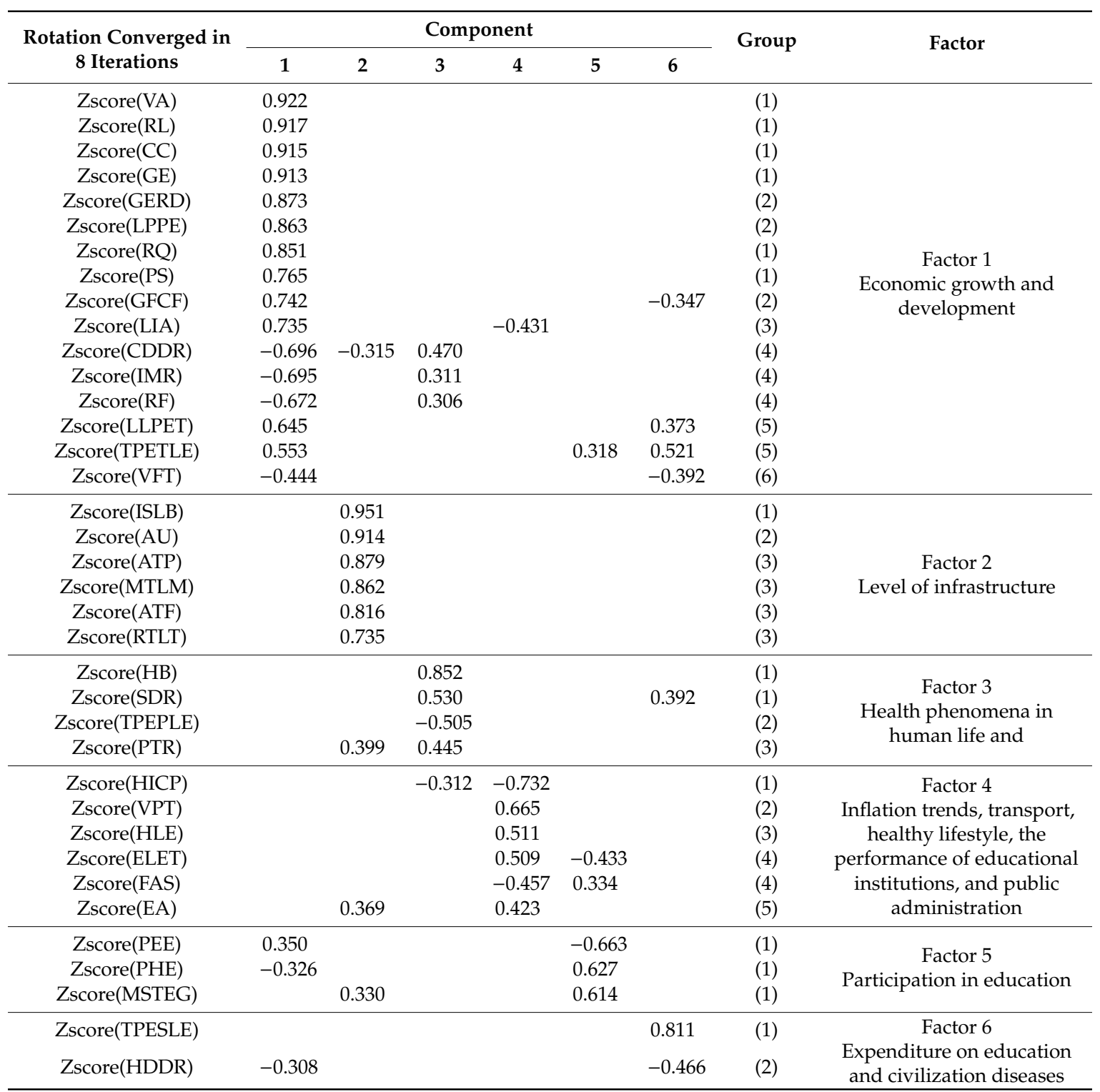


Factor 1 (economic growth and development) is composed of indicators in the following groups: (1) institutional environment, (2) macroeconomic stability, (3) technological readiness, (4) health, (5) education, and (6) infrastructure. (1) Effective institutions improve the delivery of public goods and services, address market failures, reduce transaction costs, promote transparency of entrepreneurship, and facilitate the functioning of the labor market. (2) Macroeconomic stability ensures confidence in the markets and leads to higher long-term investment and is essential for maintaining competitiveness. (3) ICT fundamentally changed the organizational structure of society, facilitating the adoption of new and more efficient ways of working and working practices, changing lifestyle, increasing productivity, and accelerating business processes. (4) Indicators of health describe human capital in terms of health status, with a particular focus on the workforce. A healthy workforce is a key factor in increasing labor market participation and labor productivity, and it strengthens competitiveness. (5) An economy based on knowledge and innovation requires educated human capital, which can adapt to changing the economic and social situation, and educational systems that successfully create key skills and abilities. (6) Transport, regardless of its type, is fully dependent on the needs of the economy and society, both in freight and passenger traffic. The functioning of the transport market is influenced much more than in other areas of government economic and social policy.

Factor 2 (level of infrastructure) is composed of indicators in the following categories: (1) macroeconomic stability, (2) training, and (3) infrastructure. (1) An indicator of income, saving, and net lending and borrowing signals the behavior of fundamental institutional, economic sectors. The relationship between income, savings, and gross capital formation determines the ability or need to finance various sectors (net lending/borrowing), which significantly affect the macroeconomic sector and, thus, the national economy. (2) Participation in education and the accessibility of higher education are considered essential for the continuous updating of skills and competencies of people that are needed for coping with the challenges of a continually evolving society based on knowledge, innovation, and ICT. (3) Modern and efficient infrastructure contributes to both economic efficiency and improving territorial equality, as it allows for maximizing local economic potential and optimum utilization of resources.

Factor 3 (health phenomena in human life and cultivation) is composed of the following indicators: (1) health, (2) education, and (3) training. (1) An indicator of hospital beds indicates the availability of healthcare in hospitals, i.e., the possibility of being admitted to treatment in hospital for some time. There is a rising trend in numbers of suicides related not only to personal problems but also to the considerable amount of hopelessness associated with the political situation in many countries or economic crisis. Economic downturn strongly tolls on the mental health of the population, because people living in uncertainty suffer from depression and psychological problems, which may subsequently result in suicides. (2) Primary education provides the basis for lifelong learning, forming relationships to education, responsible for the further motivation of children and attenuating the inequality of the social and cultural environment of the family. (3) Smaller classes are beneficial for all pupils because they are dedicated to individual attention from teachers, reflected in their ability to learn with a significant impact on their participation in further higher education.

Factor 4 (inflation trends, transport, healthy lifestyle, the performance of educational institutions, and public administration) is composed of the following indicators: (1) macroeconomic stability, (2) infrastructure, (3) health, (4) education, and (5) technological readiness. (1) The harmonized index of consumer prices (HICP) was introduced to establish a comparable index of consumer prices, so as to measure inflation trends in all EU countries as a criterion for entry into the monetary union. (2) Transport is one of the basic needs of humanity, mainly due to the different potential landscapes of the world. Transport routes can be used to move and transport people, matter, goods, energy, etc. (3) An indicator of healthy lifestyle is used to monitor health as a factor affecting productivity, to measure the employability of workers, to monitor progress in the field of accessibility, and to monitor the quality and sustainability of healthcare. (4) EU applies strategies against early school leaving; at the same time, however, it should try to widen access to higher education and improve its quality. If we manage to provide young people with the right skills and professional qualifications, it helps 
the economy in the fight against youth unemployment. The issue of inequality in financial resources in access to higher education is a key topic in recent years. Today's system of financial support for students in higher education is insufficient. Universities must be genuinely open to all who have sufficient skills to cope with studies. (5) The E-government deals with computerization of public administration. The E-government is a tool for using modern technology to simplify the lives of public administration customers while saving state funds.

Factor 5 (participation in education) is composed of indicators in one category: (1) education. An educated population is a fundamental prerequisite for the economic and social development of each country, whether currently or in the future. Governments, therefore, have an interest in broad population access to education and a wide range of educational opportunities for children and adults, which has an impact on future access to universities and a subsequent educated labor force.

Factor 6 (expenditure on education and civilization diseases) is composed of the following indicators: (1) education and (2) health. (1) Secondary schools provide education and vocational training for nearly the entire population of young people who completed their compulsory education and pre-employment or before entering college. (2) Heart disease falls into the category of lifestyle diseases, which is a group of diseases in which a significant contributor is the lifestyle and environment of industrial society. A crucial prerequisite for an economically, socially, and personally successful company is a healthy population.

The second part of FA is devoted to output factors of competitiveness representing direct or indirect outcomes of a competitive society and economy. In this paper, three dominating factors for outputs explained $70.258 \%$ of the total variability in the reference period (see Table 5), which can also be considered as a very satisfactory result. For calculation of output factors by FA, principal component analysis was used as the extraction method, and varimax with Kaiser normalization was used as the rotation method.

Table 5. Output factors—-total variance explained (Source: own calculation and elaboration).

\begin{tabular}{ccccccc}
\hline \multirow{2}{*}{ Component } & \multicolumn{3}{c}{ Initial Eigenvalues } & \multicolumn{2}{c}{ Rotation Sums of Squared Loadings } \\
\cline { 2 - 6 } & Total & \% of Variance & Cumulative \% & Total & \% of Variance & Cumulative \% \\
\hline 1 & 11.807 & 45.412 & 45.412 & 6.547 & 25.182 & 25.182 \\
2 & 3.517 & 13.526 & 58.939 & 6.088 & 23.415 & 48.597 \\
3 & 2.943 & 11.320 & 70.258 & 5.632 & 21.662 & 70.258 \\
4 & 2.314 & 8.899 & 79.157 & & & \\
5 & 1.874 & 7.210 & 86.367 & & & \\
\hline
\end{tabular}

Table 6 shows 24 indicators and their relevant output factors of competitiveness. Output factors of competitiveness for the EU member states are divided into three areas which are currently considered as the main output of the knowledge-based economy.

Table 6. Output factors—rotated component matrix (source: own calculation and elaboration).

\begin{tabular}{cccccc}
\hline \multirow{2}{*}{$\begin{array}{c}\text { Rotation Converged } \\
\text { in 5 Iterations }\end{array}$} & $\mathbf{1}$ & $\mathbf{2}$ & $\mathbf{3}$ & Group & \multirow{2}{*}{ Factor } \\
\cline { 2 - 4 } & 0.871 & & & $(1)$ & \\
Zscore(EPO) & 0.821 & & 0.305 & $(2)$ & \\
Zscore(DI) & 0.803 & & & $(1)$ & \\
Zscore(HTI) & 0.802 & & $(1)$ & \\
Zscore(ICT) & 0.801 & & $(1)$ & Factor 1 \\
Zscore(HRSTcore) & 0.778 & & $(2)$ & Economic \\
Zscore(GDP) & 0.776 & & $(1)$ & performance and \\
Zscore(HRST) & 0.734 & & $(3)$ & innovative potential \\
Zscore(PEoLMP) & 0.726 & & $(3)$ & \\
Zscore(LP) & 0.683 & & & $(1)$ & \\
Zscore(BioT) & 0.578 & & 0.382 & $(3)$ & \\
Zscore(FE) & 0.519 & & & $(4)$ & \\
Zscore(GVA) & & & & \\
\hline
\end{tabular}


Table 6. Cont.

\begin{tabular}{cccccc}
\hline \multirow{2}{*}{$\begin{array}{c}\text { Rotation Converged } \\
\text { in 5 Iterations }\end{array}$} & \multicolumn{3}{c}{ Component } & \multirow{2}{*}{ Group } & Factor \\
\cline { 2 - 4 } & $\mathbf{1}$ & $\mathbf{2}$ & $\mathbf{3}$ & & \\
\hline Zscore(ETKIedu) & & 0.982 & & $(1)$ & \\
Zscore(EiSS) & & 0.982 & & $(2)$ & Factor 2 \\
Zscore(ETKIocc) & & 0.982 & & $(1)$ & Knowledge-based \\
Zscore(ETKIgen) & & 0.982 & & $(1)$ & economy \\
Zscore(TPAp) & & 0.852 & & $(1)$ & \\
Zscore(CoE) & & 0.843 & & $(3)$ & \\
Zscore(UR) & & & -0.966 & $(1)$ & Factor 3 \\
Zscore(MU) & & & -0.937 & $(1)$ & \\
Zscore(LtUR) & & & -0.898 & $(1)$ & $(1)$ \\
Zscore(FU) & & & -0.890 & $(1)$ & Labor Market \\
Zscore(ME) & 0.392 & & 0.760 & $(1)$ & \\
Zscore(ER15to64) & 0.578 & & 0.617 & $(1)$ \\
\hline
\end{tabular}

Factor 1 (economic performance and innovative potential) is composed of indicators in the following groups: (1) innovation, (2) market size, (3) labor market efficiency, and (4) business sophistication. Factor 2 (knowledge-based economy) is composed of indicators in the following categories: (1) innovation, (2) business sophistication, and (3) market size. Factor 3 (the labor market) is composed of one indicator: (1) labor market efficiency. Based on output factors on competitiveness, it is clear that the most economically advanced countries in the world offer excellent conditions for business, with a long-term focus on supporting research and development. Substantial funding from both public budgets and business budgets is oriented to promote new ideas and a creative approach to economic activities. Domestic companies know that the future belongs to prepared companies offering something extra to their customers, i.e., the added value. In the coming years, economic growth belongs to countries experiencing "creative" companies. The profitability of large and small companies mainly depends on new ideas and thoughts. Promoting education and learning of residents is very important for the future of countries. Innovative employees determine the success of companies. The driving force is the ideas. The greatest asset of prosperous companies does not involve material things, but employees who can create new values, to respond flexibly to changing market needs and to bring constantly new ideas.

The database of factors of competitiveness (six factors for inputs and three factors for outputs) was used for the efficiency analysis by the DEA method, representing the values of input and output factors for each EU28 member state in the years of the reference periods, i.e., 2000, 2007, 2008, 2011, 2012, and 2017. Because of the DEA requirement on positive values, it was necessary to correct the initial values of input and output factors (several countries showed negative values in some factors). The conventional DEA method assumes that inputs and outputs are non-negative data. In our case, the use of standardized input or output factors from factor analysis showed that not all values met the non-negativity assumption. Thus, a data transformation was used by adding a given constant (as explained below), transforming the distribution of inputs and outputs as non-negative data; in other words, negative data cannot be directly used under any CRS DEA model. Assuming normal distribution, this distribution is transferred to non-negative data; for more information, see, e.g., Tung et al. (2018) who explored the properties of the efficiency measures for a variant of radial measure (VRM) and proposed new efficiency measures for input-oriented and output-oriented VRM models. However, there are other ways to work with negative data; e.g., Bansal and Mehra (2018) proposed a DEA efficiency model that possesses the requisite features of translation invariance and unit independence, obligatory when dealing with negative values in the original dataset coming into the analysis. Izadikhah et al. (2018) proposed a new type of DEA model for measuring and assessing the sustainability of suppliers in the presence of negative data and volume discounts. For more information about comparing different types of transformation methods, see, e.g., Chortirat et al. (2011) 
or Shu et al. (2002). Generally, data transformation is the process of converting data (in the original set of indicators and values) from one format into another format. Data transformation is, thus, both critical and essential for activities such as data integration and data management, i.e., for solving such types of problem appearing in this paper. Depending on the needs of the issues, data are transformed to make them compatible with other data, move them to another system, join them with other data, or aggregate information in the data. However, the methods of data transformation are influenced not only by the nature of the problem being solved and the purpose of the measurement for which the data are to be used, but also by the methods that will be used to solve the problem. Thus, the DEA method is also an option. As Barnum et al. (2017) explained, there are some methodological hazards associated with the use of DEA that are especially relevant to managerial decisions, but which are largely ignored in the literature, especially the problem of economic assumptions regarding input substitutions and output transformations.

For all EU28 member states across all reference years, the correction by adding a given constant was made as follows: minimum values were calculated for input factors F1-F6, where min was equal to -3.882; and the minimum values were calculated for output factors F1-F3, where min was equal to -3.387 . Based on these minimum values, the value 4.000 was added to the initial factor values; all factors gained positive values from this correction, as required for DEA. The range of values (among input factors and among output factors, as well as the range of values among input and output factors) was not changed. Therefore, only the level of values for all factors was shifted to the same extent as positive (non-negative) values for all factors. Therefore, all data indicators, in this case, input and output factors, had positive (non-negative) values. The range among values of all indicators was the same after the change as before making it. Values from negative to positive, as well as from positive to positive, were moved in the same way, i.e., differences among all values were not lost.

\section{Discussion}

According to the efficiency analysis and derived results from the solution of MPI, it emerges that the 2000-2007 efficiency ratios of the EU28 countries ranged from 0.785 to 1.653 . In the case of 2008-2011, the efficiency ratios of the EU28 countries ranged from 0.396 to 1.240. In the case of 2012-2017, the efficiency ratios of the EU28 countries ranged from 0.869 to 1.033 . From the main descriptive results for all MPI parts, i.e., MPI, ECH, and FS (see Table 7), it was possible to see that the level of efficiency measured by MPI increased among the three reference periods. However, what do these values mean concerning the MPI definition or any of its elements? If MPI is less than one, it signifies productivity is getting worse, while, if MPI is equal to one, it indicates unchanging productivity, and, if MPI is higher than one, it means productivity is getting better (Zhu 2011). From this point of view, it is necessary to say that the increasing trend of MPI seems to be positive information, but, in fact (based on mean values), it means that, in a comparison of periods 2000-2007, 2008-2011, and 2012-2017, the overall productivity of evaluated countries recorded a decreasing (negative) trend. This result is not surprising because of the nature of compared periods. Period 2000-2007 was characterized by economic growth and improving living standards in all EU member states and with the convergence process of EU12 member states to the EU15 member states. For period 2008-2011, all evaluated European countries suffered from impacts of the financial and economic crisis. Finally, in the period 2012-2017, most of these countries solved these economic problems, but this period was also characterized as a post-crisis period with a slow increasing trend of the main macroeconomic indicators. 
Table 7. MPI descriptive statistics (source: own calculation and elaboration).

\begin{tabular}{|c|c|c|c|c|c|c|c|c|c|c|}
\hline \multirow{3}{*}{\multicolumn{2}{|c|}{ Statistics }} & \multicolumn{9}{|c|}{ Period } \\
\hline & & \multicolumn{3}{|c|}{ 2000-2007 } & \multicolumn{3}{|c|}{ 2008-2011 } & \multicolumn{3}{|c|}{ 2012-2017 } \\
\hline & & MPI & ECH & FS & MPI & ECH & FS & MPI & ECH & FS \\
\hline$N$ & Valid & 28 & 28 & 28 & 28 & 28 & 28 & 28 & 28 & 28 \\
\hline \multirow{7}{*}{$\mathrm{N}$} & Missing & 0 & 0 & 0 & 0 & 0 & 0 & 0 & 0 & 0 \\
\hline & Mean & 0.97235 & 0.99416 & 0.97789 & 0.99377 & 1.00394 & 0.98987 & 0.99961 & 0.99965 & 0.99996 \\
\hline & SD & 0.159261 & 0.027815 & 0.155983 & 0.135679 & 0.013288 & 0.135008 & 0.027900 & 0.005487 & 0.027283 \\
\hline & Variance & 0.025 & 0.001 & 0.024 & 0.018 & 0.000 & 0.018 & 0.001 & 0.000 & 0.001 \\
\hline & Range & 0.867 & 0.156 & 0.867 & 0.844 & 0.070 & 0.844 & 0.165 & 0.028 & 0.165 \\
\hline & Minimum & 0.785 & 0.885 & 0.785 & 0.396 & 0.991 & 0.396 & 0.869 & 0.986 & 0.869 \\
\hline & Maximum & 1.653 & 1.041 & 1.653 & 1.240 & 1.061 & 1.240 & 1.033 & 1.014 & 1.033 \\
\hline
\end{tabular}

In Tables 8-10, the MPI results for periods 2000-2007, 2008-2011, and 2012-2017 are outlined, including information about the number of evaluated DMUs (the first column), codes of EU28 member states (the second column), efficiency scores of MPI (the third column), scores of efficiency change (the fourth column), scores of frontier shift (the fifth column), rank of EU28 member states based on MPI (the sixth, seventh, and eighth columns), and groups of countries (the ninth column). In Tables 8-10, results of the MPI and its dimensions are highlighted using the traffic light method. The range of colors of this method changes from dark to light shades of gray. Countries with the highest values of the MPI, catch-up, and frontier shift suggest a better level of efficiency and, thus, competitiveness; they are highlighted by dark shades of gray-the higher the value is, the darker the shade of gray is. On the contrary, countries with the lowest values of the MPI and its two dimensions (catch-up and frontier shift) suggest a worse level of efficiency; they are highlighted by light shades of gray-the lower the value is, the lighter the shade of gray is. Countries with values of the MPI falling between efficient (dark shades of gray) and inefficient (light shades of grey color) are highlighted by medium shades of gray.

Table 8. MPI results for period 2000-2007 (source: own calculation and elaboration).

\begin{tabular}{cccccccc}
\hline No. & DMUs & IO CRS MPI & Efficiency Change & Frontier Shift & \multicolumn{2}{c}{ Rank } & $\begin{array}{c}\text { Group of } \\
\text { Countries }\end{array}$ \\
\hline 1 & BE & 0.972 & 1.000 & 0.972 & 1. & MT & 1.653 \\
\hline 2 & BG & 0.785 & 1.000 & 0.785 & 2. & HR & 1.138 \\
\hline 3 & CZ & 0.903 & 0.994 & 0.908 & 3. & PT & 1.109 \\
\hline 4 & DK & 0.939 & 1.000 & 0.939 & 4. & RO & 1.097 \\
\hline 5 & DE & 0.880 & 1.000 & 0.880 & 5. & IE & 1.055 \\
\hline 6 & EE & 0.928 & 1.013 & 0.915 & 6. & LT & 1.049 \\
\hline 7 & IE & 1.055 & 1.000 & 1.055 & 7. & FI & 1.036 \\
\hline 8 & EL & 0.948 & 0.978 & 0.970 & 8. & SK & 1.010 \\
\hline 9 & ES & 0.858 & 1.000 & 0.858 & 9. & AT & 0.979 \\
\hline 10 & FR & 0.888 & 1.000 & 0.888 & 10. & BE & 0.972 \\
\hline 11 & IT & 0.892 & 1.000 & 0.892 & 11. & LU & 0.970 \\
\hline 12 & CY & 0.907 & 1.000 & 0.907 & 12. & EL & 0.948 \\
\hline 13 & LV & 0.904 & 0.996 & 0.907 & 13. & DK & 0.939 \\
\hline 14 & LT & 1.049 & 1.000 & 1.049 & 14. & EE & 0.928 \\
\hline 15 & LU & 0.970 & 1.000 & 0.970 & 15. & HU & 0.927 \\
\hline 16 & HU & 0.927 & 1.000 & 0.927 & 16. & PL & 0.920 \\
\hline 17 & MT & 1.653 & 1.000 & 1.653 & 17. & SE & 0.919 \\
\hline 18 & NL & 0.906 & 1.000 & 0.906 & 18. & CY & 0.907 \\
\hline 19 & AT & 0.979 & 1.041 & 0.940 & 19. & NL & 0.906 \\
\hline 20 & PL & 0.920 & 0.885 & 1.040 & 20. & LV & 0.904 \\
\hline 21 & PT & 1.109 & 1.030 & 1.077 & 21. & CZ & 0.903 \\
& & & & & & &
\end{tabular}


Table 8. Cont.

\begin{tabular}{|c|c|c|c|c|c|c|c|c|}
\hline No. & DMUs & IO CRS MPI & Efficiency Change & Frontier Shift & \multicolumn{3}{|c|}{ Rank } & $\begin{array}{l}\text { Group of } \\
\text { Countries }\end{array}$ \\
\hline 22 & $\mathrm{RO}$ & 1.097 & 1.000 & 1.097 & 22. & IT & 0.892 & \multirow{6}{*}{$\begin{array}{c}\text { 3rd } \\
\text { (5 EU15, } 1 \text { EU13) }\end{array}$} \\
\hline 23 & SI & 0.826 & 0.940 & 0.879 & 23 & FR & 0.888 & \\
\hline 24 & SK & 1.010 & 1.000 & 1.010 & 24. & $\mathrm{DE}$ & 0.880 & \\
\hline 25 & FI & 1.036 & 1.000 & 1.036 & 25. & ES & 0.858 & \\
\hline 26 & SE & 0.919 & 1.000 & 0.919 & 26. & UK & 0.827 & \\
\hline 27 & UK & 0.827 & 0.959 & 0.863 & 27. & SI & 0.826 & \\
\hline 28 & HR & 1.138 & 1.000 & 1.138 & 28. & BG & 0.785 & 4th (1 EU13) \\
\hline
\end{tabular}

Note: Belgium (BE), Bulgaria (BG), Czech Republic (CZ), Denmark (DK), Germany (DE), Estonia (EE), Ireland (IE), Greece (EL), Spain (ES), France (FR), Italy (IT), Cyprus (CY), Latvia (LV), Lithuania (LT), Luxembourg (LU), Hungary (HU), Malta (MT), Netherlands (NL), Austria (AT), Poland (PL), Portugal (PT), Romania (RO), Slovenia (SI), Slovakia (SK), Finland (FI), Sweden (SE), United Kingdom (UK), Croatia (CR).

Table 9. MPI results for period 2008-2011 (source: own calculation and elaboration).

\begin{tabular}{|c|c|c|c|c|c|c|c|c|}
\hline No. & DMUs & IO CRS MPI & Efficiency Change & Frontier Shift & & Ranl & & $\begin{array}{l}\text { Group of } \\
\text { Countries }\end{array}$ \\
\hline 1 & $\mathrm{BE}$ & 0.989 & 1.000 & 0.989 & 1. & MT & 1.240 & $\begin{array}{c}\text { 1st } \\
\text { (1 EU13) }\end{array}$ \\
\hline 2 & BG & 0.396 & 1.000 & 0.396 & 2. & $\mathrm{CY}$ & 1.120 & $\begin{array}{c}\text { 2nd } \\
\text { (1 EU13) }\end{array}$ \\
\hline 3 & $\mathrm{CZ}$ & 1.034 & 1.000 & 1.034 & 3. & $\mathrm{PT}$ & 1.075 & \multirow{16}{*}{$\begin{array}{c}\text { 3rd } \\
(8 \mathrm{EU} 15,8 \mathrm{EU} 13)\end{array}$} \\
\hline 4 & DK & 0.987 & 1.000 & 0.987 & 4. & NL & 1.065 & \\
\hline 5 & $\mathrm{DE}$ & 1.021 & 1.000 & 1.021 & 5. & LU & 1.065 & \\
\hline 6 & $\mathrm{EE}$ & 1.013 & 1.061 & 0.954 & 6. & AT & 1.062 & \\
\hline 7 & IE & 0.905 & 1.000 & 0.905 & 7. & LT & 1.042 & \\
\hline 8 & EL & 0.942 & 1.000 & 0.942 & 8. & SI & 1.039 & \\
\hline 9 & ES & 1.035 & 1.000 & 1.035 & 9. & ES & 1.035 & \\
\hline 10 & FR & 0.975 & 1.000 & 0.975 & 10. & $\mathrm{CZ}$ & 1.034 & \\
\hline 11 & IT & 1.002 & 1.000 & 1.002 & 11. & $\mathrm{RO}$ & 1.029 & \\
\hline 12 & $\mathrm{CY}$ & 1.120 & 1.000 & 1.120 & 12. & PL & 1.021 & \\
\hline 13 & LV & 0.948 & 1.000 & 0.948 & 13. & $\mathrm{DE}$ & 1.021 & \\
\hline 14 & LT & 1.042 & 1.000 & 1.042 & 14. & HR & 1.014 & \\
\hline 15 & LU & 1.065 & 1.000 & 1.065 & 15. & EE & 1.013 & \\
\hline 16 & $\mathrm{HU}$ & 0.875 & 1.000 & 0.875 & 16. & SK & 1.010 & \\
\hline 17 & MT & 1.240 & 1.000 & 1.240 & 17. & FI & 1.003 & \\
\hline 18 & NL & 1.065 & 1.000 & 1.065 & 18. & IT & 1.002 & \\
\hline 19 & AT & 1.062 & 1.000 & 1.062 & 19. & $\mathrm{BE}$ & 0.989 & \multirow{8}{*}{$\begin{array}{c}4 \text { th } \\
\text { (7 EU15, } 1 \text { EU13) }\end{array}$} \\
\hline 20 & PL & 1.021 & 1.008 & 1.013 & 20. & DK & 0.987 & \\
\hline 21 & $\mathrm{PT}$ & 1.075 & 1.030 & 1.044 & 21. & $\mathrm{SE}$ & 0.982 & \\
\hline 22 & $\mathrm{RO}$ & 1.029 & 1.000 & 1.029 & 22. & FR & 0.975 & \\
\hline 23 & SI & 1.039 & 1.000 & 1.039 & 23 & LV & 0.948 & \\
\hline 24 & SK & 1.010 & 1.000 & 1.010 & 24. & EL & 0.942 & \\
\hline 25 & FI & 1.003 & 1.000 & 1.003 & 25. & UK & 0.938 & \\
\hline 26 & SE & 0.982 & 1.000 & 0.982 & 26. & $\mathrm{IE}$ & 0.905 & \\
\hline 27 & UK & 0.938 & 0.991 & 0.947 & 27. & $\mathrm{HU}$ & 0.875 & $\begin{array}{c}\text { 5th } \\
\text { (1 EU13) }\end{array}$ \\
\hline 28 & HR & 1.014 & 1.020 & 0.993 & 28. & BG & 0.396 & $\begin{array}{c}\text { 6th } \\
\text { (1 EU13) }\end{array}$ \\
\hline
\end{tabular}


Table 10. MPI results for period 2012-2017 (source: own calculation and elaboration).

\begin{tabular}{|c|c|c|c|c|c|c|c|c|}
\hline No. & DMUs & IO CRS MPI & Efficiency Change & Frontier Shift & & & Rank & $\begin{array}{l}\text { Group of } \\
\text { Countries }\end{array}$ \\
\hline 1 & $\mathrm{BE}$ & 1.005 & 1.000 & 1.005 & 1. & EL & 1.033 & \multirow{19}{*}{$\begin{array}{c}1 \text { st } \\
\text { (12 EU15, } 7 \text { EU13) }\end{array}$} \\
\hline 2 & BG & 0.869 & 1.000 & 0.869 & 2. & EE & 1.020 & \\
\hline 3 & $\mathrm{CZ}$ & 0.993 & 1.000 & 0.993 & 3. & $\mathrm{RO}$ & 1.019 & \\
\hline 4 & DK & 1.004 & 1.000 & 1.004 & 4. & UK & 1.016 & \\
\hline 5 & $\mathrm{DE}$ & 0.996 & 1.000 & 0.996 & 5. & IE & 1.015 & \\
\hline 6 & $\mathrm{EE}$ & 1.020 & 1.014 & 1.007 & 6. & PL & 1.015 & \\
\hline 7 & IE & 1.015 & 1.000 & 1.015 & 7. & ES & 1.012 & \\
\hline 8 & EL & 1.033 & 1.000 & 1.033 & 8. & $\mathrm{LU}$ & 1.011 & \\
\hline 9 & ES & 1.012 & 1.000 & 1.012 & 9. & FI & 1.009 & \\
\hline 10 & FR & 1.002 & 1.000 & 1.002 & 10. & $\mathrm{HU}$ & 1.008 & \\
\hline 11 & IT & 1.002 & 1.000 & 1.002 & 11. & $\mathrm{BE}$ & 1.005 & \\
\hline 12 & $\mathrm{CY}$ & 0.988 & 0.986 & 1.002 & 12. & SK & 1.005 & \\
\hline 13 & $\mathrm{LV}$ & 0.989 & 1.000 & 0.989 & 13. & SE & 1.004 & \\
\hline 14 & LT & 1.001 & 1.000 & 1.001 & 14. & DK & 1.004 & \\
\hline 15 & LU & 1.011 & 1.000 & 1.011 & 15. & MT & 1.004 & \\
\hline 16 & $\mathrm{HU}$ & 1.008 & 1.000 & 1.008 & 16. & NL & 1.003 & \\
\hline 17 & MT & 1.004 & 1.000 & 1.004 & 17. & FR & 1.002 & \\
\hline 18 & $\mathrm{NL}$ & 1.003 & 1.000 & 1.003 & 18. & IT & 1.002 & \\
\hline 19 & AT & 0.997 & 1.000 & 0.997 & 19. & LT & 1.001 & \\
\hline 20 & PL & 1.015 & 1.014 & 1.001 & 20. & $\mathrm{AT}$ & 0.997 & \multirow{8}{*}{$\begin{array}{c}\text { 2nd } \\
\text { (3 EU15, } 5 \text { EU13) }\end{array}$} \\
\hline 21 & $\mathrm{PT}$ & 0.985 & 0.988 & 0.997 & 21. & $\mathrm{DE}$ & 0.996 & \\
\hline 22 & $\mathrm{RO}$ & 1.019 & 1.000 & 1.019 & 22. & HR & 0.996 & \\
\hline 23 & SI & 0.991 & 1.000 & 0.991 & 23 & $\mathrm{CZ}$ & 0.993 & \\
\hline 24 & SK & 1.005 & 1.000 & 1.005 & 24. & SI & 0.991 & \\
\hline 25 & FI & 1.009 & 1.000 & 1.009 & 25. & $\mathrm{LV}$ & 0.989 & \\
\hline 26 & SE & 1.004 & 0.999 & 1.005 & 26. & $\mathrm{CY}$ & 0.988 & \\
\hline 27 & UK & 1.016 & 1.000 & 1.016 & 27. & $\mathrm{PT}$ & 0.985 & \\
\hline 28 & HR & 0.996 & 0.991 & 1.006 & 28 & BG & 0.869 & $\begin{array}{c}\text { 3rd } \\
(1 \mathrm{EU} 13)\end{array}$ \\
\hline
\end{tabular}

Broader aspects enter the overall evaluation of economics, and these aspects are unnoticeable for DEA, i.e., parts of the qualitative assessment in line with the evaluation of overall performance. Performance is linked concerning competitiveness; a good performance in the innovation group is expected to also be a good performance in the efficiency and the basic groups as they are instrumental in increasing levels of competitiveness. As countries move along the path of development, their socio-economic conditions change, and different determinants become more important for the national level of competitiveness. As a result, the best way to improve the competitiveness of more developed countries will not necessarily coincide with the way to improve less developed countries. Consistent with the theory of economic growth and economic development, $\mathrm{CCI}$ results confirm that the most competitive countries are those with the highest level of economic development (for more information, see Annoni and Kozovska 2010; Annoni and Dijkstra 2013; or Annoni et al. 2017). It is striking that several of the top competitors are traditionally economically strong countries. At the end of the competitiveness scale, it is possible to find some countries which are unfortunately steadily the worst performers. These differences in CCI editions indicate that the EU moved far from a homogeneous entity in terms of competitiveness, but CCI results show a more polycentric pattern. Therefore, part of the explanation of inequalities among the EU member states has to do with differences in competitiveness.

An economic entity with a low level of competitiveness may not have similar opportunities as a highly competitive economic entity. This fact remains and is confirmed. However, what does it mean for efficiency in competitiveness? In the case of efficiency analysis of competitiveness and in the time comparison analysis of change, the results are just a little bit different. Why? The concept of competitiveness may then be necessary not only to evaluate why some countries grow faster than 
others, but also why some countries have a better and more efficient distribution of competitiveness over time than others. Is a high level of competitiveness necessarily associated with a high level of efficiency, and vice versa? It may not always be the case because evaluated countries have a lower level of input; these countries were able to achieve competitiveness at the level of CCI. While the CCI value may not be high in the less competitive countries, it is necessary to compare the values of inputs and outputs. In DEA efficiency analysis, although the IO CRS MPI value is not so high, overall, it is possible to state that the country operates more efficiently at the end than at the beginning of the reference period. Such a conclusion is relevant by comparing values of inputs and outputs, and the fact that outputs are achieved with given inputs.

More specifically, based on MPI results in periods 2000-2007, 2008-2011, and 2012-2017, it is important to notice that many European countries achieved a value of MPI higher than 1.000 and, thus, productivity is increasing. As mentioned above, part of the explanation of the large inequalities within EU countries is linked with the differences in competitiveness. Finally, Tables 8-10 show reordered countries, from best to worst, their MPI score, and the corresponding rank. The results state positive trends within the community of EU member states. Based on the MPI results, it is clear that the best efficiency changes in competitiveness comparing reference years were achieved by countries belonging to the group of EU13 countries, i.e., new EU member states, than in the case of countries belonging to the group of EU15 countries, i.e., the old EU member states. This fact is not surprising, because it has the following key political implications with several reasons/factors:

- The new EU member states constantly fall into the category of less developed and competitive states based on gross domestic product (GDP) per head in Purchasing Parity Standard (PPS), which is the reason for their inclusion in the appropriate categorization stage of development (see Annoni and Kozovska 2010; Annoni and Dijkstra 2013; or Annoni et al. 2017);

- The association of each country with the relevant stage of development testifies to its competitive advantages and disadvantages and determines its weaknesses. A medium stage of development is associated with economies primarily driven by factors such as lower skilled labor and basic infrastructures. Aspects related to good governance and quality of public health are considered basic inputs in this framework. An intermediate stage of development is characterized by labor market efficiency, quality of higher education, and market size, factors which contribute to a more sophisticated economy and more significant potential for competitiveness. In the high stage of development, factors related to innovation, business sophistication, and technological readiness are necessary inputs for innovation-driven economies (Annoni and Dijkstra 2013);

- The threshold defining the level of GDP as a percentage of EU average was taken as a reference as it is the criterion for identifying countries and their regions eligible for funding under the established criteria of the EU regional policy framework. European funds are an essential tool for regional development and reducing economic, social, and territorial disparities among European countries and their regions. Reducing disparities have a significant impact on competitiveness, and these two concepts are, thus, the EU complementary objectives. Of the total budget allocated to regional policy, a substantial part goes just to the NUTS 2 regions of EU13 countries (i.e., the basic regions for the application of regional policies classify based on the EU Nomenclature of Territorial Units for Statistics), where development is significantly supported;

- New EU member states are often considerably dependent on exports into the old EU member states and on the flow of money for this exchange shift.

The above facts can raise the question of whether the results automatically provide the prerequisites for improving the development of the new EU member states. This is the question of the convergence process de jure and de facto. For the Baltic, Balkan, and central and eastern European countries, joining the EU held the implicit promise of economic convergence to Western European standards of living represented by the old EU member states. As officially stated by the European Commission (2019), this was true for both the first wave of eastern enlargement in 2004 and the subsequent accession of Bulgaria 
and Romania in 2007 and finally Croatia in 2013. As of the 15th anniversary of the 2004 accession, this expectation was largely met; access to the European single market (i.e., internal market) created new business opportunities, triggered vast capital flowed to the new EU member states, and facilitated their integration into global supply chains. The catch-up process, thus, gained additional impetus during the accession talks and negotiation and again upon joining the EU. Although a significant gap remains today, it is shrinking at a rapid pace, highlighting central improvements among the new EU member states, as well as convergence of the group of EU13 countries to the group of EU15 countries in the following areas: income convergence; convergence in labor productivity; convergence in workforce; convergence in participation rates; convergence in educational attainment; convergence in competitiveness; convergence in quality of governance; convergence in research, development, and innovation; convergence in digital connectivity; convergence in openness to trade and integration into European supply chains; and convergence in openness to foreign direct investment.

Figure 2 constitute the box plots of all parts of MPI, i.e., MPI, ECH, and FS. Box plots of each MPI part show data skewness and kurtosis to mean values, reflected by the equal location of the median $\left(\mathrm{X}_{50}\right)$ between the upper $\left(\mathrm{X}_{75}\right)$ and lower $\left(\mathrm{X}_{25}\right)$ quartiles. In the cases of MPI, ECH, and FS, data are skewed to the upper levels-the median is shifted to the upper quartile $\left(X_{75}\right)$. The shapes of box plots also indicate the symmetrical layout. Each box plot represents data from the normal distribution, not only due to its symmetry but also due to the position of the median, which lies almost in the middle of the rectangle. In the context of efficiency analysis, the outliers and extreme values are interesting, i.e., the highest or lowest values of MPI in comparison to values of MPI of other countries in the evaluated sample within the reference period. The current version of the EU has 28 member states and, therefore, we aim to have relevant analysis for all EU countries and not only the selected sample. Therefore, DMUs present the EU countries in the form of outliers, and extreme values are not excluded from our empirical analysis. Our analysis aims to have comprehensible results for the entire sample of countries and not a partial sample; we are concerned about the diversity that the EU is characterized by, as highlighted by its motto "unity in diversity".

The classification of EU15 and EU13 member states concerning the nature of technical and technological change is illustrated in Figure 3. In all reference periods, the location of all European countries is recorded concerning results of ECH and FS. Evaluated countries are divided into two groups (the EU15 member states and the EU13 member states) for a better comparison of common features and differences. It is convenient to remind the reader that $\mathrm{ECH}$ and FS values of 1.000 mean no productivity change, values higher than 1.000 mean that productivity is improving, and values lower than 1.000 mean that productivity is deteriorating. From this point of view, it is possible to divide European countries into four categories or quadrants. Via the illustration of Figure 2, information about differences in efficiency recorded by MPI among three reference periods is confirmed. Across the reference periods, most European countries are located in quadrants with a low level of FS, and a higher or lower level of ECH. It means that efficiency change is especially caused by the difference in the production possibility frontier because of the technology development between reference years, i.e., technology frontier shift. This fact is positive information concerning factors of competitiveness; it signifies that countries can utilize their internal factor endowment efficiently and can apply technological progress for boosting their competitive advantages, i.e., they contribute to qualitative-based economic growth, allowing raising the steady state. On the other side, some European countries are located in quadrants with a high level of FS, and a more upper or lower level of ECH. It means that efficiency change is due to a change in the relative efficiency of the evaluated country with respect to other countries, due to the production possibility frontier between reference years, i.e., technical efficiency change. This fact is not such positive information because it means that countries extract their efficiency based on shifts in sources of competitiveness, i.e., they make changes in composition and quantity of sources based on their exchange business with other countries. The characteristic of technical efficiency change, thus, contributes only to quantitative-based economic 
growth, which has its limits; this is disconcerting concerning limited sources, utilization of sources, and possibility/impossibility of their recovery.
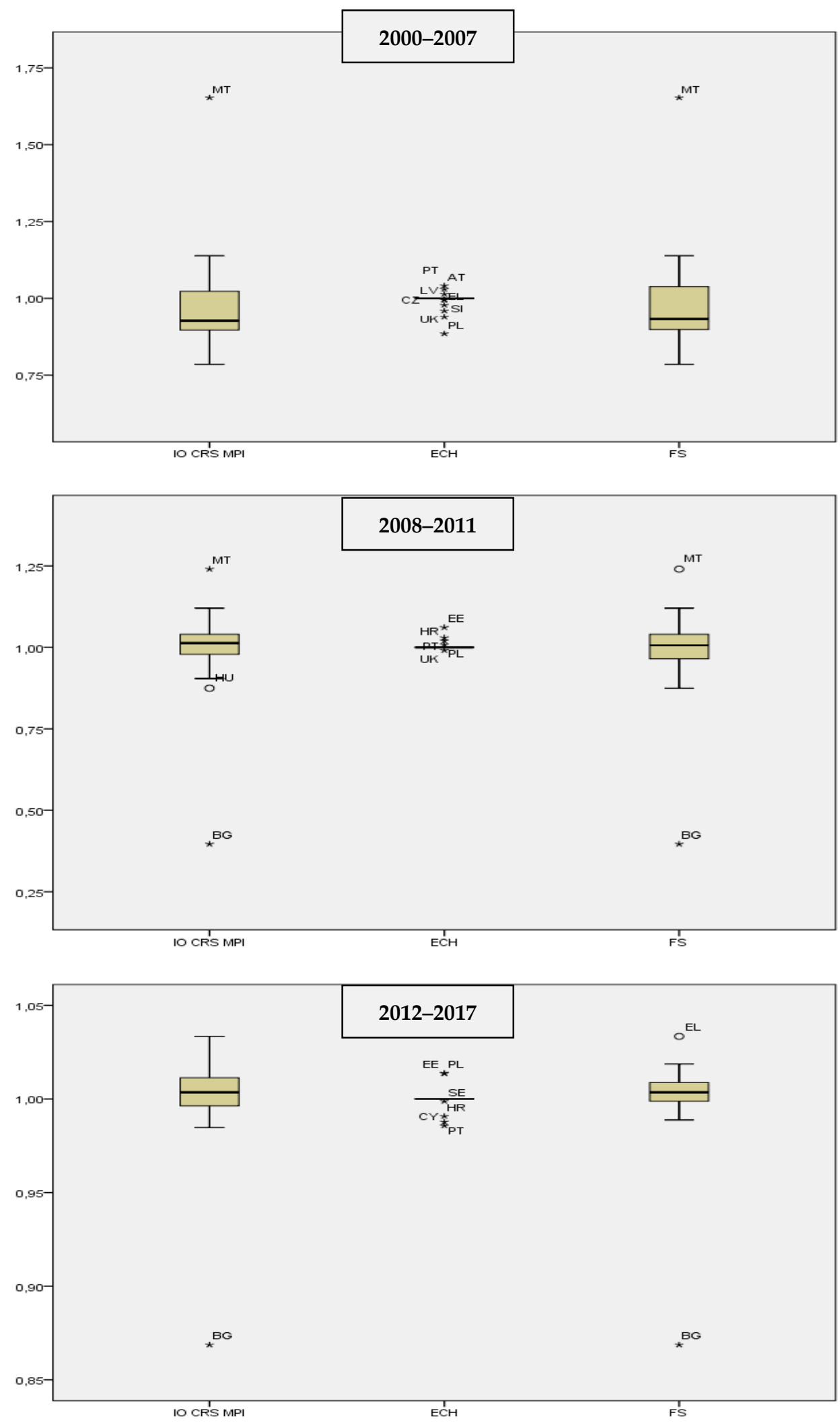

Figure 2. Box plots of Malmquist productivity index (MPI), change in relative efficiency (ECH), and change in production possibility frontier (FS)—outliers (source: own calculation and elaboration). 

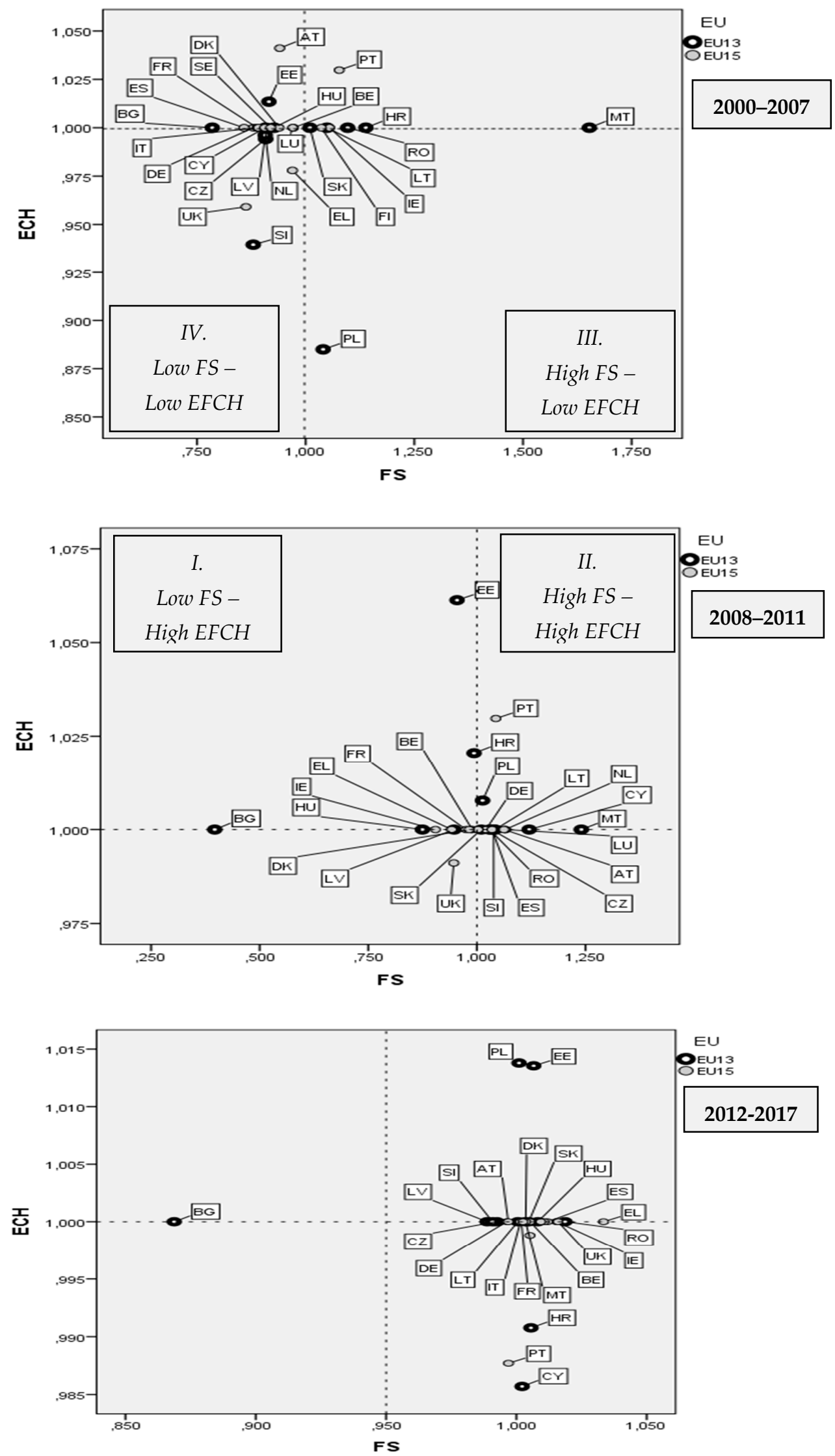

EU

OEU13

2012-2017

Figure 3. Comparison of EU15 and EU13 distances in ECH and FCH (source: own calculation and elaboration). 
The practicality or applicability of these results in terms of economic policy is, however, limiting because the results only refer to relative efficiency. What does it mean? In the framework of the evaluation, it is necessary to move from efficiency to effectiveness, i.e., instead of conducting economic policy activities based on their setting and objectives; however, this cannot be done using the DEA method. For future research, it is necessary to rely on the evaluation of the relationship between output and outcome (effectiveness) and not input and output (efficiency), which the DEA method evaluates. The reconstructed or newly built technical and transport infrastructure, the reconstruction of buildings and companies, and buying new technical tools, i.e., factual or physical re-modernization should be taken in account, as well as the possibilities of proper use in activities generating added value for the economy, i.e., qualitative, competitive advantage, which is key for the knowledge economy. This should be the topic of future research, i.e., how the factor endowment of the given economy contributes to its growth and how the economy can use not only its quantitative but also its qualitative competitive advantages. To this end, however, it is necessary to find suitable methods used in the evaluation of effectiveness. The quality and utility of assessment could be improved further by developing a more integrated and ongoing approach to evaluation.

All these factors affect the convergence trend of the new EU member states and their regions to the old EU member states, and the growth in the old EU member states has an implicative impact on growth in the new EU member states. This growth may have the same degree in EU13 countries as in EU15 countries or may be higher. Many of the differences in economic growth and quality of life within a country may be explained by the differences in competitiveness. Countries with more paved roads, with better institutions, with better business environment, and with better human capital, for example, may experience faster economic growth and a clearer reduction in poverty levels (Charles and Zegarra 2014). All these trends and facts have very significant effects on the competitiveness of all EU member states, changing the efficiency/inefficiency development. The internal variation and heterogeneity also underline the inevitable steps needed at the national level. Policies oriented to solve the main economic and social problems of citizens may then not only focus on the improvement of the aggregate or average indicators of competitiveness, but also on the reduction of the regional differences in competitiveness. Effective thematic policies and efficient use of public spending on the established aims will help the overall efficiency of the whole system, ensuring desired outcomes-effectiveness that has a significant impact on reducing disparities and improving competitiveness.

The White Paper on the Future of Europe makes a powerful statement about the current precarious state of European integration and its uncertain future. The continuing effects of the financial, economic, and migration crises are associated with reduced confidence and trust in democratic institutions and politicians, and a rise in populism, threatening the unity of the EU. A significant cause is the unequal impact of globalization and technological change on different parts of the EU. Thus, the EU not only needs to accelerate sustainable growth but also to resume convergence so that all parts of the EU can exploit the opportunities from the globalization of trade and technological change. The past three decades were characterized by trade liberalization, the rise of global value chains, and global production networks. The integration of emerging countries challenged the EU's attractiveness as a production location, because of import competition and off-shoring.

Furthermore, technological change and digital transformation (the fourth production revolution) is associated with jobless growth and concerns that the EU is falling behind technologically. Europe generally has a strong position concerning advances in technology, value added, productivity, profitability, and profits, but there are significant questions about its technological leadership. There are significant opportunities from the structural change that the EU is well placed to exploit. The cost advantages of some emerging economies are eroding, labor costs are becoming a less critical factor in location decisions, and some supply chains are being shortened to ensure greater control. These trends do not guarantee the renewed competitiveness of developed economies but depend on the ability of developed economies to effect the necessary structural transformation. Structural change across the EU requires a different policy and institutional focus on "ecosystems" of open, interconnected 
networks of stakeholders, cooperating through strategic partnerships able to respond rapidly and flexibly to technological, market, and social changes. Disruptive innovation and creativity require multidisciplinary and open models of collaboration. The support of an environment for such ecosystems will unavoidably need to be tailored to specific national, regional, or even local contexts. Policy packages need to be integrated and coordinated, delivered at a national, regional, and local level, while being adapted to the needs of different territories (Bachtler et al. 2017).

Many observers believe that Europe is at the beginning of a new industrial revolution, considered to be the fourth such leap forward labeled Industry 4.0. The ubiquitous use of sensors, the expansion of wireless communication and networks, the deployment of increasingly intelligent robots and machines, as well as increased computing power at a lower cost and the development of "big data" analytics, have the potential to transform the way goods are manufactured in Europe. This new digital industrial revolution holds the promise of increased flexibility in manufacturing, mass customization, increased speed, better quality, and improved productivity. However, to capture these benefits, enterprises will need to invest in equipment, information and communication technologies (ICT), and data analysis, as well as the integration of data flow throughout the global value chain. The EU supports industrial change through its industrial policy and research and infrastructure funding. Member states are also sponsoring national initiatives such as Industrie 4.0 in Germany, the Factory of the Future in France and Italy, and Catapult centers in the United Kingdom (UK). However, challenges remain. The need for investment, changing business models, data issues, legal questions of liability and intellectual property, standards, and skill mismatches are among the challenges that must be met if benefits are to be gained from new manufacturing and industrial technologies. If these obstacles can be overcome, Industry 4.0 may help reverse the past decline in industrialization and increase total value added from manufacturing to a targeted $20 \%$ of all value added by strategy Europe 2020 .

Based on the facts mentioned in the two paragraphs above, the issue of reducing disparities among the EU member states and improving internal and external competitiveness can be solved by the current technical and digital revolution (Industry 4.0), especially via the EU cohesion policy instruments, e.g., in the form of Cohesion Policy 4.0 and through the European Structural and Investment Funds for current programming period 2014-2020. The challenge for the EU as a whole and the individual member state policy-makers is to develop or adopt policy frameworks and strategies that will stimulate sustainable growth, in a manner that ensures greater inclusiveness, especially in access to employment and capacity for entrepreneurship. This demands a more granular approach to structural policy, tailored better to the specific conditions of the different types of regions and communities across the EU. Different strategies are needed for frontier regions, intermediate regions (some catching up but others only keeping pace), and lagging regions. Existing EU strategies-from Lisbon strategy for period 2000-2010 to current strategy Europe 2020 for period 2010-2020-are only partially successful, with limited results about the scale of the challenge.

Notwithstanding specific achievements, strategies were over-ambitious about the resources available, the deficits in governance (especially on coherence and the coordination of policies), and the performance of interventions. Importantly, policy responses gave inadequate recognition of the spatial unevenness of current and development needs and challenges for economic growth and development in the EU. Looking forward, any new EU strategic approach needs to recognize the lessons from the past and be realistic about what can be achieved. With relatively limited budgetary resources at the EU level, the EU will need to establish some principles for a new EU strategy. The critical requirement is a coherent, consistent, and mutually enforcing policy framework. Sectoral policies cannot deliver on a new EU agenda without integrated territorial policy packages. Equally, integrated territorial policy approaches cannot achieve prosperity and inclusive growth in the EU without well-designed sectoral and structural policies and reforms.

The EU model of integration delivered unmatched long-term growth and economic and social convergence. However, the model is threatened by the effects of the financial and economic crises on employment opportunities and living standards. The EU needs both to accelerate sustainable growth 
and ensure that all parts of the EU can exploit the growing globalization of trade and technological change. Structural transformation should be central to renewed policy priorities, requiring a new balance between policies for competitiveness and cohesion. The pursuit of economic and social cohesion is a collective task of both national and EU policies. Member states have the primary responsibility for the conduct and coordination of their economic policies to meet cohesion objectives. The same obligation applies to all EU policies and actions, including the implementation of the internal market. The agenda for Cohesion 4.0 is, thus, a much broader task than for cohesion policy alone. It requires the EU member states to demonstrate that they implemented structural reforms to support growth and cohesion before uploading domestic interests to the European level. It also underscores the necessity of an integrated approach to structural transformation and cohesion under all EU regulatory and investment policies (Bachtler et al. 2017).

The informative ability of the results depends on the methods used; the results, as such, are dependent on the selected measurement methods that affect their limits and usage assumptions. Generally, the results of each analysis and method depend on the data used, i.e., they depend on data quality. There exist different assumptions that your data must meet for the method used to give a valid result. In the case of our analysis, the limitations are lined primarily with using principal component analysis (PCA). When we chose to analyze our data using PCA, part of the process involved checking to make sure that the data we wanted to examine could be analyzed using PCA. In practice, checking for these assumptions required using SPSS Statistics to carry out a few more tests, as well as to think a little bit more about our data. When analyzing our data using SPSS Statistics, one or more of these assumptions may be violated (i.e., not met). This is not uncommon when working with real-world data rather than textbook examples. However, even when our data fail certain assumptions, there is often a solution to try and overcome this. The particulars that we had to deal with in our analysis mainly concerned that data should be suitable for data reduction and there should be no significant outliers. Involving DEA assumptions, we had to deal with the homogeneity of units, sampling adequacy, i.e., comparison of the number of units and the number of input and output variables, and last but not least isotonicity. All of these limitations were addressed, tested, and explained in the article.

\section{Conclusions}

Currently, the EU consists of 28 member states and is continually expanding to include new countries. The considerable geographic, demographic, and cultural diversity of the EU also brings differences in the socio-economic position of the EU member states. Different results in economic performance and living standards of the population indicate the status of the competitiveness of every country. Each country should know its competitive advantages and disadvantages and aim to strengthen advantages and reduce disadvantages, i.e., key factors of competitiveness. One of the main aims of the paper was to define the main factors of socio-economic development that determine the competitiveness level of EU member states. Based on FA results, it is possible to state that, in most of the cases, the old EU member states reflect the best results in driven forces of competitiveness (inputs aspects) as an assumption for better outcomes of economic activities and functioning of society (outputs aspects). The competitiveness of territory resides not only in the competitiveness of its constituent firms and their interactions, but also in the broader assets and social, economic, institutional, and public attributes of the country itself. The notion of competitiveness is as much about qualitative factors and conditions (such as untraded networks of informal knowledge, trust, social capital, and the like) as it is about quantifiable attributes and processes (such as inter-firm trading, patenting rates, labor supply, and so on). Furthermore, the causes of competitiveness are usually attributed to the effects of an aggregate of factors rather than the impact of any individual factor. The sources of competitiveness may also originate at a variety of geographical scales, from the local through to the regional, national, and even international. Therefore, the possibility of isolating the precise effects of any individual factor is limited, as mentioned by Martin (2003). The emergence of new perspectives in creating competitive advantages at the national level clearly emphasizes the role of local factors and economic initiatives in 
the general economic development of a country through conceptual constructions such as industrial clusters or districts, innovation networks, or competence centers.

From efficiency analysis, it is evident that there are significant economic development disparities between European countries. For smoothing of these disparities, the EU authorities are developing various strategies to further the economic growth of all EU member states and especially their regions both in the old and new EU member states. The pace of convergence also has an impact on the level of economic growth of the EU as such. Catch-up of less developed economies (the EU13 countries) can occur through several different channels. As these effects occur simultaneously, they can cause feedback to other economic developments, meaning that many of the dynamics can be mutually reinforcing, thus having a positive impact not only on the group of EU13 countries but also on the group of EU15 countries. From efficiency analysis, the five channels can be distinguished in the EU context, i.e., intensification of trade, increases in investment in human and physical capital, financial integration, improvements in institutional quality, and innovation and technological progress. As the European Commission (2019) explained, the nature of the convergence process is in line with enlargement process, and any transition from a centrally planned economy to a market-based one is bound to produce a rise in productivity, economic growth, and per capita income. The main channels through which this occurs is through greater allocative efficiency and, perhaps less clear-cut, higher capital investment rates and more effortless technology transfer.

When the Baltic, Balkan, and central and eastern European countries joined the EU in 2004-2007-2013, they became part of the European single market, i.e., one territory without any internal borders or other regulatory obstacles to the four free movements (movement of goods, services, persons, and capital). Membership of the European single market raised their integration with the rest of the EU, stimulated macroeconomic competitiveness, as well as market competition and trade, improved efficiency, raised quality, and reduced prices. It boosted trade with the old EU member states of the EU15 countries, as well as among each other. It also had a large impact on incomes and welfare of citizens in the EU as a whole. Not only access to the European single market but also the EU cohesion policy had a significant impact on the convergence pace, i.e., the EU cohesion policy supports the catch-up process in Europe's regions. The Baltic, Balkan, and central and eastern European countries joining the EU became eligible for this support from the EU cohesion policy programs. The results of DEA analysis, thus, confirm the potential benefits of the EU cohesion policy with significant output gains in the long-run period due to sizeable productivity improvements. As officially stated by the European Commission (2019) concerning the impact of the EU cohesion policy, in the medium-run period, the productivity-enhancing effects of infrastructure investment, research and development-promoting policies, and human capital investments become gradually stronger and generate large output effects in the long-run period; therefore, there are permanent positive output gains in the EU as a whole.

Many European countries, even those with an acceptable level of economic growth, are developing new strategic plans aiming at keeping up in the "rat race" of international and interregional competition to attract the best investments. A policy focusing on improving the physical and social environment may be one of the essential tools to attract the natural territorial sources of economic growth. This competition may be seen as the result of an increasing variety of production opportunities in a growing number of regions across the EU (Lambooy and Boschma 2001). The new variety evolved with the development of new technologies and new organizational structures. Many countries feel the threat of being outperformed by other countries and, therefore, they have to utilize their competitive advantages efficiently. Bringing together different development factors which illustrate single aspects of competitiveness gives a first impression of the overall international competitiveness of European countries and shows the diversity that exists within the EU territory. Among the essential driving forces influencing future territorial development are demographic development (including migration), economic integration, transport, energy, agriculture and rural development, climate change, further EU enlargements, and territorial governance. A significant role is played by exogenous factors having 
an impact on regional competitiveness, as mentioned. Current theories of regional competitiveness emphasize the significance of "soft" factors such as human, cultural (knowledge and creativity), and socio-institutional capital, environmental quality, etc. A wide range of soft location factors is, thus, of increasing importance. "Soft" factors like governance, culture, and natural environment are part of territorial potentials and offer synergies for jobs and the growth agenda. The potentials for these "soft factors" differ widely between areas. Quality living environments and access to environmental and cultural amenities are among factors that attract investment and people to a location, which is very important for competitiveness for each country and its competitive advantage and factor endowment. Currently, hazards do not undermine the competitiveness of a region. Only a few places have shallow exposure to the main natural and technological hazards in Europe, and climate change is expected to increase the risk of hazards in the future. To gaze into the future, it is necessary to understand the driving forces that shape territorial development and various possible future developments and interrelations with the territory each driving force might bring. Bringing them together into integrated prospective scenarios is then the final challenge.

Author Contributions: Conceptualization, L.M., M.S., and J.H.; methodology, M.S. and J.H.; software, M.S. and J.H.; validation, L.M. and M.S.; formal analysis, L.M. and M.S.; investigation, L.M.; resources, L.M.; data curation, M.S.; writing-original draft preparation, L.M. and M.S.

Funding: This research received no external funding.

Acknowledgments: The paper was supported by grant No. 17-23411Y of the Czech Science Agency, the Operational Program Education for Competitiveness-Project No. CZ.1.07/2.3.00/20.0296, and the SGS project (SP2014/111) of the Faculty of Economics, VŠB Technical University of Ostrava.

Conflicts of Interest: The authors declare no conflicts of interest. The funders had no role in the design of the study; in the collection, analyses, or interpretation of data; in the writing of the manuscript, and in the decision to publish the results. 


\section{Appendix A}

Table A1. DEA method in countries' macroeconomy and KBE studies (source: own review and elaboration).

\begin{tabular}{|c|c|c|c|}
\hline Authors & Datasets & Inputs and Outputs Used in DEA & Key Results \\
\hline Cheng Chen 2017 & $\begin{array}{l}20 \text { Taiwan counties/cities in the } \\
\text { period 1999-2013 }\end{array}$ & $\begin{array}{l}\text { Inputs and outputs: variables for the } \\
\text { department of economic development, } \\
\text { variables for the department of public } \\
\text { security, variables for the department of } \\
\text { social welfare, variables for the department } \\
\text { of education }\end{array}$ & $\begin{array}{l}\text { The police security department is the most efficient in most } \\
\text { counties/cities in the period 1999-2013, and the economic } \\
\text { development department is the second most efficient one in } \\
2002-2005 \text { and after 2009. There exist urban-rural gaps in the } \\
\text { efficiency scores between counties and cities, between } \\
\text { service-type and non-service type counties/cities, and among } \\
\text { different regions. }\end{array}$ \\
\hline Nurboja and Košak 2017 & $\begin{array}{l}11 \text { southeast European countries; } 82 \\
\text { banks from EU member countries } \\
\text { and } 157 \text { banks from non-EU } \\
\text { countries; period 1999-2013 }\end{array}$ & $\begin{array}{l}\text { Inputs: borrowed funds, labor, and physical } \\
\text { Capital } \\
\text { Outputs: loans, securities, and other earning } \\
\text { assets, ratio of equity }\end{array}$ & $\begin{array}{l}\text { Statistically significant cost efficiency gap between EU and } \\
\text { non-EU banking systems in the region, where on average EU } \\
\text { banking systems tend to be more cost efficient than their } \\
\text { non-EU counterparts. }\end{array}$ \\
\hline Wu et al. 2014 & $\begin{array}{l}21 \text { Organisation for Economic } \\
\text { Co-Operation and Development } \\
\text { (OECD) countries }\end{array}$ & $\begin{array}{l}\text { Inputs: real physical capital per worker, real } \\
\text { knowledge capital per worker } \\
\text { Outputs: Real income per worker, real } \\
\text { income per } \\
\text { worker over unemployment rate, real } \\
\text { income per } \\
\text { worker over air pollutants }\end{array}$ & $\begin{array}{l}\text { Research and development expenditures, the proxy variable for } \\
\text { knowledge capital, can indeed improve countries' efficiency } \\
\text { scores, implying that the endogenous growth theory is } \\
\text { supported in OECD countries. Whether the undesirable } \\
\text { outputs are included in the DEA models and are properly } \\
\text { treated is crucial in the evaluation of efficiency values. }\end{array}$ \\
\hline Foddi and Usai 2013 & 271 regions in 29 European countries & $\begin{array}{l}\text { Inputs: Total intramural R\&D expenditure, } \\
\text { Economically active population with tertiary } \\
\text { education } \\
\text { attainment } \\
\text { Outputs: Number of the European Patent } \\
\text { Office (EPO) patent applications per priority } \\
\text { year and residence region of inventors }\end{array}$ & $\begin{array}{l}\text { Malmquist index shows extremely differences in productivity } \\
\text { dynamics across regions, important differences are between the } \\
\text { core and periphery of Europe. }\end{array}$ \\
\hline Rabar 2013 & $\begin{array}{l}\text { Croatian regions, three-year period } \\
\qquad 2005-2007\end{array}$ & $\begin{array}{l}\text { Inputs: registered unemployment rate, } \\
\text { number of support allowance users } \\
\text { Outputs: share of the secondary sector in } \\
\text { Gross Valued Added (GVA), gross fixed } \\
\text { capital formation in fixed assets, level of } \\
\text { import coverage by export, number of } \\
\text { graduate students, Gross Domestic Product } \\
\text { (GDP) }\end{array}$ & $\begin{array}{l}\text { Among } 63 \text { observed entities, } 15 \text { turned out to be efficient. The } \\
\text { highest efficiency results were achieved in } 2007 \text { toward both } \\
\text { orientations. None of the } 21 \text { counties was efficient during the } \\
\text { entire period. The worst efficiency results were achieved in } \\
\text { 2006, while the lowest average efficiency was achieved in } 2005 \text {. } \\
\text { Average efficiency scores for all three periods are greater in } \\
\text { output orientation than in input orientation. }\end{array}$ \\
\hline
\end{tabular}


Table A1. Cont.

\begin{tabular}{|c|c|c|c|}
\hline Authors & Datasets & Inputs and Outputs Used in DEA & Key Results \\
\hline $\begin{array}{l}\text { Goryushina and Mesropyan } \\
2013\end{array}$ & $\begin{array}{l}\text { Russian regional economy } \\
\text { performance for the period from } 2008 \\
\text { to } 2010\end{array}$ & $\begin{array}{l}\text { Inputs: number of cattle, organizations } \\
\text { acreage under crops, average number of } \\
\text { employees, power capacity, equipment parks } \\
\text { Outputs: gross grain yield, } \\
\text { production of milk, production of livestock } \\
\text { and poultry }\end{array}$ & $\begin{array}{l}\text { Agrarian production of the south of Russia shows the reserve } \\
\text { of stability, and the southern regions belong to Pareto-efficient } \\
\text { set of Russian regions. Only } 4 \text { regions among } 13 \text { of the south } \\
\text { are estimated as having the stable decline. } \\
\text { The economic development opportunities of this regions are } \\
\text { significant, nevertheless, the considerable potential of regions is } \\
\text { not used. }\end{array}$ \\
\hline Afzal and Lawrey 2012 & $\begin{array}{l}\text { Association of southeast Asian } \\
\text { nations (ASEAN) in two years } 1995 \\
\text { and 2010, World Development } \\
\text { Indicators (WDI) and World } \\
\text { Competitiveness Yearbook (WCY) }\end{array}$ & $\begin{array}{l}\text { Inputs: Export/GDP, import/GDP, Foreign } \\
\text { Direct Investment (FDI) inward flows, R\&D } \\
\text { expenditure, intellectual property rights, } \\
\text { education expenditure, net enrolment ratio } \\
\text { at secondary school, knowledge transfer rate } \\
\text { (university to industry), FDI inflows } \\
\text { Outputs: Real GDP growth, scientific and } \\
\text { technical publications per } 1000 \text { population, } \\
\text { computer users per } 1000 \text { population, } \\
\text { high-tech export }\end{array}$ & $\begin{array}{l}\text { Indonesia in knowledge acquisition; Singapore, South Korea } \\
\text { and Thailand in knowledge production; Singapore in } \\
\text { knowledge distribution; the Philippines, and South Korea in } \\
\text { knowledge utilization are the most productive and } 100 \% \\
\text { efficient countries in either one or both of the years } \\
\text { investigated. }\end{array}$ \\
\hline Deliktas and Balcilar 2005 & $\begin{array}{l}25 \text { transition economies (east } \\
\text { European, Baltic, and other former } \\
\text { Soviet Union countries) }\end{array}$ & $\begin{array}{l}\text { Inputs: total labor force, gross capital } \\
\text { formation } \\
\text { Outputs: real GDP }\end{array}$ & $\begin{array}{l}\text { No technological progress, but over the whole period } \\
1991-2000 \text { there was a technological regress, and also decline in } \\
\text { the average annual total factor productivity. Results suggest } \\
\text { that, on average, chance in technical efficiency is outweighed } \\
\text { by the technical regress. }\end{array}$ \\
\hline Tan et al. 2008 & $\begin{array}{l}\text { WDI-2001 dataset for } 54 \text { developing } \\
\text { countries }\end{array}$ & $\begin{array}{l}\text { Inputs: Research and Development }(\mathrm{R} \& \mathrm{D}) \\
\text { expenditure, labor productivity, average } \\
\text { schooling } \\
\text { Outputs: mobile phone users, internet users, } \\
\text { Personal Computer (PC) penetration, } \\
\text { high-tech exports }\end{array}$ & $\begin{array}{l}\text { India, Indonesia, Thailand, and China are inefficient countries } \\
\text { due to the outflow of human resources. }\end{array}$ \\
\hline Christopoulos 2007 & $\begin{array}{l}\text { Selected OECD and non-OECD } \\
\text { countries }\end{array}$ & $\begin{array}{l}\text { Inputs: human capital, openness } \\
\text { Output: real GDP }\end{array}$ & $\begin{array}{l}\text { Movements towards openness increase the efficiency } \\
\text { performance of non-OECD countries. }\end{array}$ \\
\hline Mohammad 2007 & $\begin{array}{l}\text { Selected Asia-Pacific countries. } \\
\text { Datasets } \\
\text { collected in 1996, 2000, and } 2003\end{array}$ & $\begin{array}{l}\text { Inputs: government expenditure as \% of } \\
\text { GDP } \\
\text { Outputs: real GDP growth, real employment } \\
\text { rate, inflation rate }\end{array}$ & Only seven of 25 selected countries are efficient. \\
\hline
\end{tabular}


Table A1. Cont.

\begin{tabular}{|c|c|c|c|}
\hline Authors & Datasets & Inputs and Outputs Used in DEA & Key Results \\
\hline Ramanathan 2006 & $\begin{array}{l}\text { Selected Middle Eastern and north } \\
\text { African countries, WDI-1999 }\end{array}$ & $\begin{array}{l}\text { Inputs and outputs: ratio of labour to } \\
\text { population, life expectancy, primary } \\
\text { education teachers, GNP per capita, literacy } \\
\text { rate, mortality rate, etc. }\end{array}$ & $\begin{array}{l}\text { Bahrain, Jordan, Kuwait, and the United Arab Emirates (UAE) } \\
\text { are the most efficient while Yemen is the least efficient country. }\end{array}$ \\
\hline Malhotra and Malhotra 2006 & $\begin{array}{l}\text { European Union (EU15) nations } \\
\text { against one another from } 1993 \text { to } 2006\end{array}$ & $\begin{array}{l}\text { Seven economic variables: current account } \\
\text { as \% of GDP, current account as \% of exports, } \\
\text { GDP per head of population, inflation, } \\
\text { international liquidity, real GDP growth, } \\
\text { exchange rate stability }\end{array}$ & $\begin{array}{l}\text { All the participating nations were not equally efficient at the } \\
\text { beginning of the economic integration in } 1993 \text {. Economic } \\
\text { integration did help in achieving convergence in economic } \\
\text { performance of EU15 nations because } 13 \text { of the } 15 \text { nations were } \\
\text { efficient in } 1998 \text {. After 1998, there is lack of convergence in the } \\
\text { performance of EU } 15 \text { nations and some nations performed } \\
\text { more efficiently in contrast to other nations. }\end{array}$ \\
\hline Halkos and Tzeremes 2005 & $\begin{array}{l}51 \text { Greek prefectures, three decades } \\
\qquad(1980,1990,2000)\end{array}$ & $\begin{array}{l}\text { Inputs: Number of hospital beds per } 1000 \\
\text { citizens, number of doctors per } 1000 \text { citizens, } \\
\text { number of public schools per } 1000 \text { students, } \\
\text { number of public buses per } 1000 \text { citizens } \\
\text { Outputs: GDP as a percentage of the mean } \\
\text { GDP of the country, difference of } \\
\text { urban-rural population, number of new } \\
\text { houses per } 1000 \text { citizens }\end{array}$ & $\begin{array}{l}\text { Results of effect of fiscal policies on the Greek prefectures: the } \\
\text { resources of a prefecture do not necessarily ensure the } \\
\text { efficiency of this prefecture. }\end{array}$ \\
\hline Hsu et al. 2008 & $\begin{array}{l}\text { World Competitiveness Yearbook } \\
\qquad 2004\end{array}$ & $\begin{array}{l}\text { WCY-2004 pillars used as input and output } \\
\text { variables for OECD and non-OECD } \\
\text { countries }\end{array}$ & $\begin{array}{l}\text { Indonesia and Argentina outperform in all the efficiency scores } \\
\text { and Turkey, Poland, and Mexico appear to have stable } \\
\text { efficiencies. Twenty-nine countries are shown to be efficient. }\end{array}$ \\
\hline Hseu and Shang 2005 & OECD countries, 1991-2000 & $\begin{array}{l}\text { Inputs: wood pulp capacity, paper and } \\
\text { paperboard capacity, number of employees } \\
\text { Outputs: wood pulp, paper and } \\
\text { paperboard }\end{array}$ & $\begin{array}{l}\text { The productivity change of pulp and paper industry in OECD } \\
\text { countries ranged from Switzerland's } 0.9 \% \text { to Japan's } 2.4 \% \text { over } \\
\text { the sampled period. The Nordic nations (Finland, Norway, and } \\
\text { Sweden) recorded } 1.2-1.5 \% \text { improvement in their performance. } \\
\text { The productivity of the Canadian pulp and paper industry } \\
\text { increased by } 2 \% \text {, while that of its United States counterpart } \\
\text { increased only by } 0.8 \% \text {. The results also showed that the last } \\
\text { decade's productivity growth was attributed more to the } \\
\text { technical change than efficiency change. }\end{array}$ \\
\hline
\end{tabular}


Table A1. Cont.

\begin{tabular}{|c|c|c|c|}
\hline Authors & Datasets & Inputs and Outputs Used in DEA & Key Results \\
\hline Breuss et al. 2000 & $\begin{array}{l}\text { Central and eastern European } \\
\text { candidate countries to the EU }\end{array}$ & $\begin{array}{l}\text { Three Copenhagen criteria: } \\
\text { (i) political criteria-i.e., the establishment of } \\
\text { democracy and the } \\
\text { protection of human rights and minorities; } \\
\text { (ii) economic criteria-the building up of a } \\
\text { functioning market economy able to } \\
\text { withstand the competition on the single } \\
\text { market; } \\
\text { (iii) acquis criterion-i.e., the complete } \\
\text { takeover of the legal status of the Union plus } \\
\text { the acceptance of its targets (meaning } \\
\text { monetary and political union) }\end{array}$ & $\begin{array}{l}\text { Macroeconomic performance of most of the Central and Eastern } \\
\text { European countries (CEEC) lies far behind the EU standards, in } \\
\text { foreign trade some of the CEECs already perform better than } \\
\text { some EU countries. Interestingly, authors find out that some } \\
\text { CEECs were already better prepared for the European } \\
\text { Monetary Union (EMU) than many EU member states. }\end{array}$ \\
\hline Golany and Thore 1997 & $\begin{array}{c}\text { Statistical department } \\
\text { of } 72 \text { developed and } \\
\text { developing countries in 1970-1985 }\end{array}$ & $\begin{array}{l}\text { Inputs: real investment as \% of GDP, real } \\
\text { government consumption as \% of GDP, } \\
\text { education expenditure as \% of GDP } \\
\text { Outputs: real GDP growth, infant mortality, } \\
\text { enrolment ratio for secondary schools, } \\
\text { welfare payments }\end{array}$ & $\begin{array}{l}\text { Japan, the United States of America (USA), Canada and the } \\
\text { Asian tigers show increasing returns to scale (IRS); } \\
\text { Scandinavian and very poor developing countries show } \\
\text { decreasing returns to scale (DRS). }\end{array}$ \\
\hline
\end{tabular}




\section{References}

Adusei, Michael. 2016. Modelling the efficiency of universal banks in Ghana. Quantitative Finance Letters 4: 60-70. [CrossRef]

Afzal, Munshi Naser Ibne, and Roger Lawrey. 2012. Evaluating the Comparative Performance of Technical and Scale Efficiencies in Knowledge-Based Economies (KBEs) in ASEAN: A Data Envelopment Analysis (DEA) Application. European Journal of Economics, Finance and Administrative Sciences 51: 81-95.

Annoni, Paola, and Lewis Dijkstra. 2013. EU Regional Competitiveness Index 2013. Luxembourg: Publication Office of the European Union.

Annoni, Paola, and Kornelia Kozovska. 2010. EU Regional Competitiveness Index 2010. Luxembourg: Publication Office of the European Union.

Annoni, Paola, Lewis Dijkstra, and Nadia Gargano. 2017. EU Regional Competitiveness Index 2016. Working Paper WP 02/2017. Brussels: European Commission.

Avkiran, Necmi K. 2006. Productivity Analysis in the Service Sector with Data Envelopment Analysis. SSRN Working Paper 2006. Brisbane: The University of Queensland.

Bachtler, John, Joaquim Oliveira Martins, Peter Wostner, and Piotr Zuber. 2017. Towards Cohesion Policy 4.0: Structural Transformation and Inclusive Growth. Brussels: Regional Studies Association.

Balcerowicz, Leszek, Andrzej Rzónca, Lech Kalina, and Aleksander Łaszek. 2013. Economic Growth in the European Union. Brussels: Lisbon Council asbl.

Bansal, Pooja, and Aparna Mehra. 2018. Multi-period additive efficiency measurement in data envelopment analysis with non-positive and undesirable data. OPSEARCH 55: 642-61. [CrossRef]

Barnum, Darold, Jason Coupet, John Gleason, Abagail McWilliams, and Annaleena Parhankangas. 2017. Impact of input substitution and output transformation on data envelopment analysis decisions. Applied Economics 49: 1543-56. [CrossRef]

Breuss, Fritz, Mikulás Luptácik, and Bernhard Mahlberg. 2000. How far away are the CEECs from the EU economic standards? A data envelopment analysis of the economic performance of the CEECs. In EI Working Papers/Europainstitut, 35. Vienna: Vienna University of Economics and Business.

Caves, Douglas W., Laurits R. Christensen, and W. Erwin Diewert. 1982. The Economic Theory of Index Numbers and the Measurement of Input, Output, and Productivity. Econometrica 50: 1393-414. [CrossRef]

Chandola, Varun, Banerjee Arindam, and Vipin Kumar. 2009. Anomaly detection: A survey. ACM Computing Surveys 41: 1-58. [CrossRef]

Charles, Vincent, and Luis Felipe Zegarra. 2014. Measuring regional competitiveness through Data Envelopment Analysis: A Peruvian case. Expert Systems with Applications 41: 5371-81. [CrossRef]

Charnes, Abraham, William W. Cooper, and Edwardo L. Rhodes. 1978. Measuring the efficiency of decision making units. European Journal of Operational Research 2: 429-44. [CrossRef]

Cheng Chen, Chih. 2017. Measuring departmental and overall regional performance: Applying the multi-activity DEA model to Taiwan's cities/counties. Omega 67: 60-80. [CrossRef]

Christopoulos, Dimitris K. 2007. Explaining country's efficiency performance. Economic Modelling 24: $224-35$. [CrossRef]

Chortirat, Thunyaporn, Boonorm Chomtee, and Juthaphorn Sinsomboonthong. 2011. Comparison of four data transformation methods for weibull distributed data. Kasetsart Journal-Natural Science 45: 366-83.

Conte, Andrea, Philip Schweizer, Adriaan Dierx, and Fabienne Ilzkovitz. 2009. An Analysis of the Efficiency of Public Spending and National Policies in the Area of RED. European Economy-Occassional Papers 54. Brussels: European Commission.

Cooper, William W., Lawrence M. Seiford, and Kaoru Tone. 2007. Data Envelopment Analysis: A Comprehensive Text with Models, Applications, References and DEA-Solver Software. New York: Springer.

Deliktas, Ertugrul, and Mehmet Balcilar. 2005. A Comparative Analysis of Productivity Growth, Catch-Up, and Convergence in Transition Economies. Emerging Markets Finance and Trade 41: 6-28. [CrossRef]

Drucker, Peter. 2001. The Efficiency of the Decision Makers. Bucharest: Editura Destin.

Easterly, William, and Ross Levine. 2012. The European Origins of Economic Development. NBER Working Paper Series 18162; Cambridge: National Bureau of Economic Research.

Esser, Klaus, Wolfgang Hillebrand, Dirk Messner, and Jörg Meyer-Stamer. 1995. Systemic Competitiveness. New Governance Patterns for Industrial Development. London: Frank Cass. 
European Commission. 2019. 11 Trends for 11 Countries on EU Convergence: The EU Enlargement Countries in the Baltics, Balkans and Central and Eastern Europe. Available online: https://ec.europa.eu/info/conference-15thanniversary-2004-eu-enlargement-looking-back-looking-forward/edited-volume_en (accessed on 1 April 2019).

Färe, Rolf, Shawna Grosskopf, and C. A. Knox Lovell. 1994a. Production Frontiers. Cambridge: Cambridge University Press.

Färe, Rolf, Shawna Grosskopf, Marry Norris, and Zhongyang Zhang. 1994b. Productivity Growth, Technical Progress and Efficiency Change in Industrialized Countries. The American Economic Review 84: 66-83.

Farrell, Michael James. 1957. The measurement of productivity efficiency. Journal of the Royal Statistical Society 120: 253-90. [CrossRef]

Foddi, Marta, and Stefano Usai. 2013. Technological catching up among European regions. Lessons from Data Envelopment Analysis. WP4/02 Search Working Paper. Brussels: European Commission.

Gardiner, Ben, Ron Martin, and Peter Tyler. 2004. Competitiveness, Productivity and Economic Growth across the European Regions. Journal of Regional Studies 38: 1045-67. [CrossRef]

Ghosh, Jayati, Peter Havlik, Marcos Poplawski-Ribeiro, and Waltraut Urban. 2009. Models of BRICs' Economic Development and Challenges for EU Competitiveness. Vienna: The Vienna Institute for International Economics Studies.

Golany, Boaz, and Sten Thore. 1997. Restricted best practice selection in DEA: An overview with a case study evaluating the socio-economic performance of nations. Annals of Operations Research 73: 117-40. [CrossRef]

Goryushina, Evgenija, and Karine Mesropyan. 2013. Economic Inequality and Political Instability Measuring by DEA and Alternative Indices: State of the Art and Research Perspectives for Cross-Regional Studies. Der Donauraum 52: 445-64. [CrossRef]

Hair, Joseph F., William C. Black, Barry J. Babin, and Roplh E. Anderson. 2009. Multivariate Data Analysis. Upper Saddle River: Prentice Hall.

Halkos, George, and Nickolaos Tzeremes. 2005. A DEA Approach to Regional Development. MPRA Paper 3992. Available online: https://mpra.ub.uni-muenchen.de/id/eprint/3992 (accessed on 1 July 2007).

Hseu, Jiing-Shyang, and Jui-Kou Shang. 2005. Productivity Changes of Pulp and Paper Industry in OECD Countries, 1991-2000: A Non-Parametric Malmquist Approach. Forest Policy and Economics 7: 411-22. [CrossRef]

Hsu, Maxwell, Xueming Luo, and Gary H. Chao. 2008. The Fog of OECD and Non-OECD Country Efficiency: A Data Envelopment Analysis Approach. The Journal of Developing Areas 42: 81-93.

Hwang, Yun-Gi, Soohyun Park, and Daecheol Kim. 2018. Efficiency Analysis of Official Development Assistance Provided by Korea. Sustainability 10: 2697. [CrossRef]

Izadikhah, Mohammad, Reza Farzipoor Saen, and Razieh Roostaee. 2018. How to assess sustainability of suppliers in the presence of volume discount and negative data in data envelopment analysis? Annals of Operations Research 269: 241-67. [CrossRef]

Jiang, Huichen, and Yifan He. 2018. Applying Data Envelopment Analysis in Measuring the Efficiency of Chinese Listed Banks in the Context of Macroprudential Framework. Mathematics 6: 184. [CrossRef]

Lacko, Roman, and Zuzana Hajduová. 2018. Determinants of Environmental Efficiency of the EU Countries Using Two-Step DEA Approach. Sustainability 10: 3525. [CrossRef]

Lambooy, Jan G., and Ron A. Boschma. 2001. Evolutionary economics and regional policy. The Annals of Regional Science 35: 113-31. [CrossRef]

Lukovics, Miklos. 2009. Measuring Regional Disparities on Competitiveness Basis. In Regional Competitiveness, Innovation and Environment. Edited by Zoltán Bajmócy and Imre Lengyel. Szeged: JATE Press, pp. 39-53.

MacGregor Pelikánová, Radka. 2017. European myriad of approaches to parasitic commercial practices. Oeconomia Copernicana 8: 167-80. [CrossRef]

Makridou, Georgia, Kostas Andriosopoulos, Michael Doumpos, and Constantin Zopounidis. 2014. An Integrated Approach for Energy Efficiency Analysis in European Union Countries. Working Paper 2014.02. Chania: Technical University of Crete.

Malhotra, Rashmi, and Davinder K. Malhotra. 2006. Evaluating the efficiency of European Union integration. International Journal of Commerce and Management 19: 233-52. [CrossRef]

Mandl, Ulrike, Adriaan Dierx, and Fabienne Ilzkovitz. 2008. The Effectiveness and Efficiency of Public Spending. Brussels: European Commission-Directorate General for Economic and Financial Affairs. 
Martin, Ron. 2003. A Study on the Factors of Regional Competitiveness. Available online: http://ec.europa.eu/ regional_policy/sources/docgener/studies/pdf/3cr/competitiveness.pdf (accessed on 1 September 2003).

Melecký, Lukáš. 2018. The main achievements of the EU structural funds 2007-2013 in the EU member states: efficiency analysis of transport sector. Equilibrium. Quarterly Journal of Economics and Economic Policy 13: 285-306. [CrossRef]

Mihaiu, Diana Marieta, Alin Opreana, and Marian Pompiliu Cristescu. 2010. Efficiency, effectiveness and performance of the public sector. Romanian Journal of Economic Forecasting 1: 132-47.

Mohammad, Nordin. 2007. A Linear Programming Formulation of Macroeconomic Performance: The Case of Asia Pacific. Matematika 23: 29-40.

Nurboja, Bashkim, and Marko Košak. 2017. Banking efficiency in South East Europe: Evidence for financial crises and the gap between new EU members and candidate countries. Economic Systems 41: 122-38. [CrossRef]

Ocubo, Toshihiro. 2012. Antiagglomeration subsidies with heterogeneous firms. Journal of Regional Science 52: 285-87. [CrossRef]

Otsuka, Akihiro. 2014. Analysis of Productive Efficiency in Japanese Regional Economies. Studies in Regional Science 44: 453-65. [CrossRef]

Rabar, Danijela. 2013. Assessment of Regional Efficiency in Croatia using Data Envelopment Analysis. Croatian Operational Research Review 4: 76-88.

Ramanathan, Ramakrishnan. 2006. Evaluating the comparative performance of countries of the Middle East and North Africa: A DEA Application. Socio-Economic Planning Sciences 40: 156-67. [CrossRef]

Seiford, Lawrence M., and Joe Zhu. 1999. An investigation of returns to scale in data envelopment analysis. Omega 27: 1-11. [CrossRef]

Shu, Guoping, Beiyan Zeng, Deanne Wright, and Oscar Smith. 2002. Impact of Data Transformation on the Performance of Different Clustering Methods and Cluster Number Determination Statistics for Analyzing Gene Expression Profile Data. Paper presented at 14th Annual Conference on Applied Statistics in Agriculture, Manhattan, Kansas, April 28-30; pp. 94-110.

Staníčková, Michaela. 2017. Can the implementation of the Europe 2020 Strategy goals be efficient? The challenge for achieving social equality in the European Union. Equilibrium. Quarterly Journal of Economics and Economic Policy 12: 383-98.

Stevens, James P. 1986. Applied Multivariate Statistics for the Social Sciences. Mahwah: Lawrence Erlbaum Associates.

Tan, Hui-Boon, Chee-Wooi Hooy, Sardar M.N. Islam, and Alex Manzoni. 2008. Relative efficiency measures for the knowledge economies in the Asia Pacific region. Journal of Modelling in Management 3: 111-24.

Toloo, Mehdi, Mona Barat, and Atefeh Masoumzadeh. 2015. Selective measures in data envelopment analysis. Annals of Operations Research 226: 523-642. [CrossRef]

Tung, Shiue-Jen, Guo-Ya Gan, and Wen-Li Chyr. 2018. Efficiency Measures for VRM Models Dealing with Negative Data in DEA. Journal of Marine Science and Technology-Taiwan 26: 180-84.

Watt, Andrew, and Andreas Botsch. 2010. After the Crisis: Towards a Sustainable Growth Model. Brussels: European Trade Union Institute.

Wu, Po-Chin, Tzu-Hsien Huang, and Sheng-Chieh Pan. 2014. Country Performance Evaluation: The DEA Model Approach. Social Indicators Research 118: 835-49. [CrossRef]

Zhu, Joe. 2011. Manual DEA Frontier-DEA Add-In for Microsoft Excel. Available online: http://www.deafrontier. net (accessed on 1 May 2011).

(C) 2019 by the authors. Licensee MDPI, Basel, Switzerland. This article is an open access article distributed under the terms and conditions of the Creative Commons Attribution (CC BY) license (http://creativecommons.org/licenses/by/4.0/). 